KEYWORDS

Public expenditures

Investments

Gross domestic product

Economic growth

Employment

Public sector

Measurement

Evaluation

Statistical methodology

Statistical data

Latin America

\section{Benedict Clements}

Division Chief,

Western Hemisphere Department,

International Monetary Fund

œbclements@imf.org

Christopher Faircloth

Economist,

Western Hemisphere Department,

International Monetary Fund

œ cfaircloth@imf.org

Marijn Verhoeven

Deputy Division Chief

Fiscal Affairs Department

International Monetary Fund

œmverhoeven@imf.org
CEPAL REVIEW 93 - DECEMBER 2007

\section{Public expenditure in \\ Latin America: \\ trends and key policy issues}

\author{
Benedict Clements, Christopher Faircloth \\ and Marijn Verhoeven
}

$\mathrm{T}$

his article examines trends in public spending in Latin America from

the mid-1990s to 2006. It also examines key policy issues, including the cyclicality of spending, public investment, public employment and social spending, finding that primary expenditures as a share of gross domestic product have trended upward for the past ten years, driven by increases in current spending, in particular for social expenditures. Fluctuations in real spending have continued to follow a pro-cyclical pattern. The authors conclude that there is substantial scope to improve the efficiency of public investment, public employment and social spending. 


\section{I}

\section{Introduction}

The role that public spending should play in fostering economic growth remains an important element in the policy debate in Latin America. Beyond their macroeconomic impact, expenditure policies can affect growth through a number of channels, including their effects on the development of physical and human capital. ${ }^{1}$ These policies have an especially important role in Latin America, given the wide disparities in living standards among the rich and the poor in the region (de Ferranti, Perry et al., 2004). Notwithstanding recent reductions, public debt ratios remain high, limiting the ability of governments to meet social needs and bolster the region's infrastructure.

This article assesses trends in public expenditures in Latin America and discusses key policy issues for the coming years. The analysis covers 17 countries and reviews trends in spending from the mid-1990s to 2006. ${ }^{2}$ In addition, the article examines several key expenditure policy issues, including: (i) the cyclicality of government spending, (ii) public investment, (iii) public employment and (iv) social expenditures.

\section{II}

\section{Trends in public spending}

\section{Overview of fiscal trends}

Fiscal balances generally weakened in the latter half of the 1990s. Rising primary spending tended to outpace increases in revenues, contributing to a deterioration in primary balances of over one percentage point of GDP (figure 1). ${ }^{3}$

Average primary balances fluctuated relatively little over the period, although there were significant differences across countries. Revenues rose by an average of about one percentage point of GDP in about half of the countries of the region.

\footnotetext{
$\square$ The authors would like to acknowledge the useful comments received from an anonymous referee, as well as those from Pablo Pereira, Roberto Steiner, and numerous colleagues in the IMF Fiscal Affairs and Western Hemisphere Departments. Valuable research assistance was provided by Takahiro Atsuta, Priya Joshi and Victoria Gunnarsson.

${ }^{1}$ For a more extensive overview of how fiscal policy and government expenditures affect growth, see Clements, Gupta and Inchauste (2004).

2 The 17 countries covered by the study are Argentina, Bolivia, Brazil, Chile, Colombia, Ecuador, Mexico, Peru, Paraguay, Uruguay and Venezuela (Bolivarian Republic of) (referred to collectively in the article as "South America and Mexico") and Costa Rica, El Salvador, Guatemala, Honduras, Nicaragua and Panama ("Central America"). Figures for 2006 refer to IMF estimates as of April 2007.
}

Fiscal positions have improved this decade, thanks largely to the strengthening of revenues. After a slight decline in 2000-2002, average primary balances have trended upward, with primary surpluses in recent years substantially exceeding their mid-1990s levels. This is attributable largely to surging revenues, especially from export commodities. Revenues have risen by an average of about 3.5 percentage points of GDP since 2002, with oil producers experiencing a boost in receipts of over 4.5 percentage points. ${ }^{4}$ Bolivia, Chile and Peru have also benefited from the boom in metals prices and exportbased revenues. In 2002, average non-commodity export revenues also rose in the 17 countries covered by the study, but the increase of about $1 \%$ of GDP was lower than that of commodity export revenues. Higher primary surpluses, together with improvements in macroeconomic

\footnotetext{
3 Figures based on the broadest definition of government available. For 14 of the 17 countries, expenditure data refer to the public sector or non-financial public sector (that is, general government spending, plus the capital expenditures of public enterprises). For Argentina and Mexico, expenditures also include the current outlays of public enterprises (e.g., wages), although in the case of the former country these outlays are very small. For Chile, the data cover general government.

4 The oil-producing countries are Ecuador, Mexico and Venezuela (Bolivarian Republic of).
} 
FIGURE 1

Latin America: fiscal trends

(As a percentage of $g d p)^{a}$

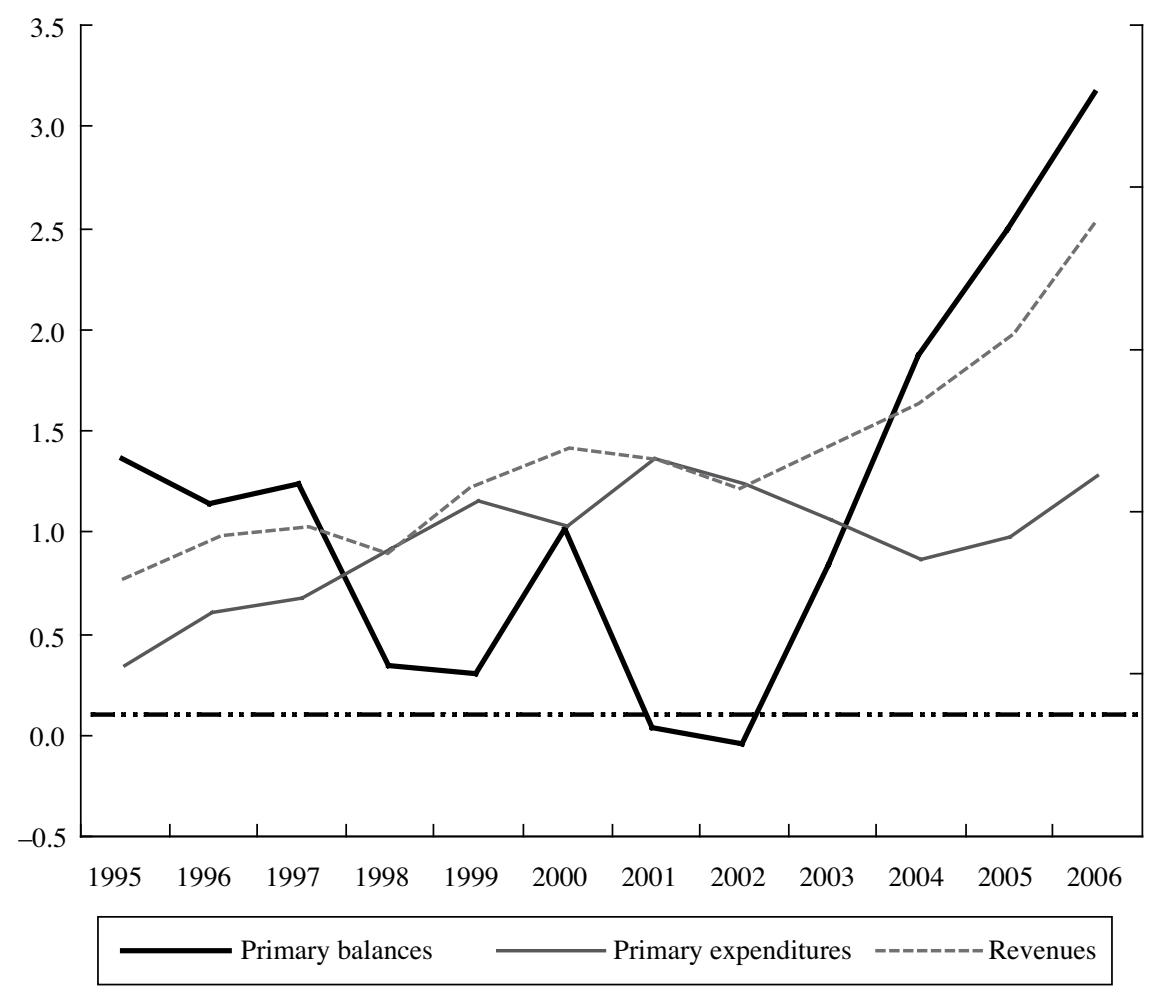

Source: Authors' calculations.

${ }^{\text {a }}$ Unweighted average of 17 countries. Based on the broadest definition of government available. See footnote 3 in the main text for details.

policies, have helped to sustain the region's ongoing economic expansion. ${ }^{5}$

Notwithstanding strengthened primary balances, public debt ratios remain above desirable levels in many countries in the region. On an unweighted average basis, public debt in Latin America is estimated at $44 \%$ of GDP. Given that the prudent maximum level of debt for a typical emerging market is generally much lower - according to some estimates, as low as $25 \%$ of GDP - debt burdens remain an obstacle to the achievement of macroeconomic stability. ${ }^{6}$

\section{Trends in government expenditure}

(a) Trends across country groups and sub-periods

Primary outlays have drifted upward over time. In both Central America and South America and Mexico,

5 See imf (2006b) for further discussion.

${ }^{6} \mathrm{See}$, for example, IMF (2003). primary spending has edged upward as a share of GDP since the mid-1990s (figure 2). The rise has not been continuous, however. During what could be called the "first phase" of increases (1995-2001), primary spending rose by three percentage points of GDP (the median increase was $0.5 \%$ ). Then, during the economic downturn of 2002 and the first years of the recent recovery (2003-2004), a widespread decline in average spending with respect to GDP occurred, with 11 of the 17 countries trimming spending-to-GDP ratios between 2001 and 2004. More recently, there has been a "second phase" of spending increases, coinciding with the maturation of the recovery, with outlays rising by about two percentage points of GDP between 2004 and 2006. With this second round of spending increases, outlays have now surpassed their previous peak ratio to GDP of 2001.

Spending increases were widespread across countries during the first phase (1995-2001). Outlays rose in all but two countries of the region (Paraguay and Panama). At the same time, the size of the increases 
varied considerably across countries. In Brazil, spending rose by 5.5 percentage points of GDP, driven by higher non-wage current outlays. In Honduras and Uruguay, outlays rose by over $5.5 \%$ of GDP, with a large increase in the wage bill explaining much of the increase. In Bolivia and Chile, spending also rose briskly (by about $4.5 \%$ of GDP), owing to higher outlays for pensions (Bolivia) and higher social spending and capital expenditures (Chile).

In the second phase (2004-2006), spending increases were broad-based across the region. Expenditures climbed in about two thirds of the countries, but with wide variation across countries, as evidenced by the fact that the median increase in spending $(0.5$ percentage point of GDP) was lower than the mean increase (1\% of GDP). The disparity reflected especially large increases in the Bolivarian Republic of Venezuela (9.5\% of GDP), as well as Argentina, Brazil and Colombia (2.5\% of GDP in all three cases). In contrast, Central America experienced a slight decline in spending (about $0.5 \%$ of GDP), because the countries in that subregion have not benefited from the buoyant export commodity revenues enjoyed by South America and Mexico.

In terms of level of public spending, there has been no tendency towards convergence in the size of government across the region. In fact, some of the countries with relatively higher levels of initial spending in 1995 have experienced the sharpest increases in outlays (figure 3). One notable exception is Uruguay, where fiscal adjustment in the wake of the crisis earlier in the current decade has left spending/GDP ratios below those prevailing in the mid-1990s.

Spending data for the general government alone indicate a similar pattern. The analysis of spending trends shown in figures 1 to 3 is based on the widest definition of government available, and in many cases includes the capital spending of public enterprises. General government primary spending data for 12 countries, however, also show a similar pattern, with these outlays rising from about 20\% of GDP in 1995 to $23 \%$ of GDP in 2006.

FIGURE 2

Latin America: primary public spending by region

(As a percentage of $G D P)^{a}$

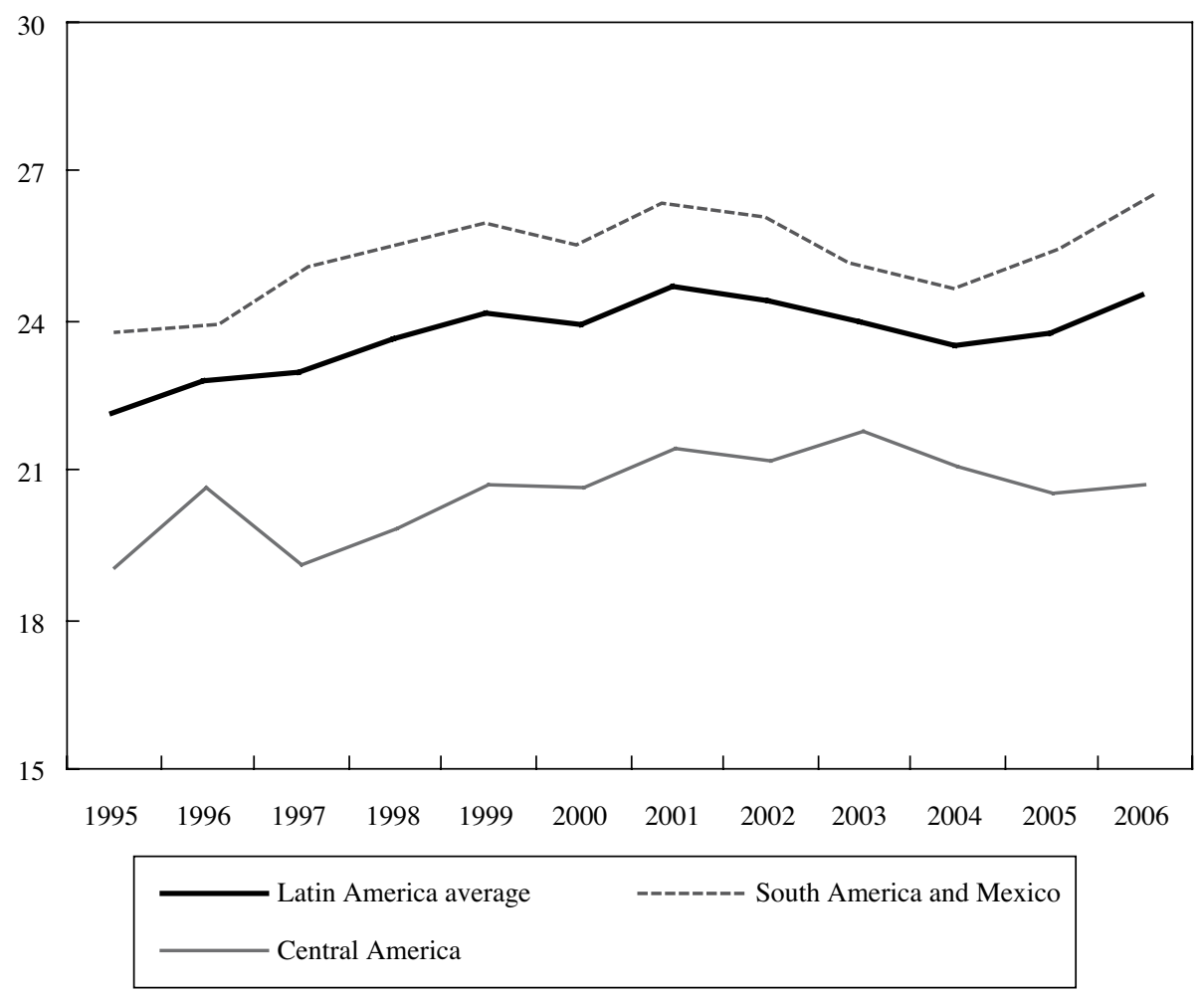

Source: Authors' calculations.

${ }^{\text {a }}$ Unweighted average of 17 countries. Based on the broadest definition of government available. 


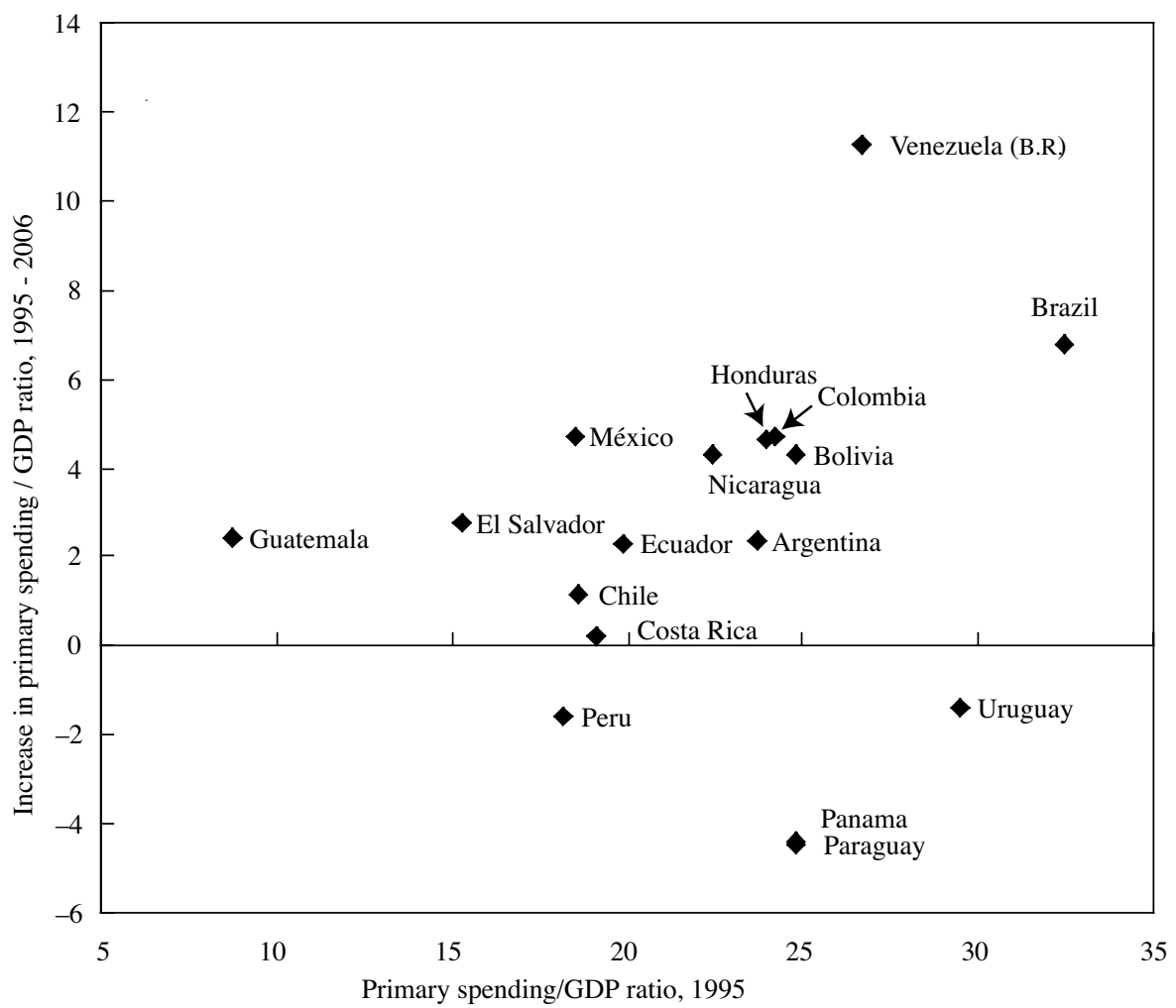

Source: Authors' calculations.

However, given that spending may evolve differently at the different levels of government (including regional governments), additional analysis of these trends would be a useful line of additional inquiry.

In some cases, budget rigidities have contributed to rising spending. In Brazil, for example, the revenue-based fiscal consolidation strategy in place since 1999, combined with extensive budget rigidities, has contributed to the large increase in spending since the mid-1990s. Revenue earmarking, in particular, led to spending growth as efforts to increase revenues intensified. Budget rigidities have also led to higher spending in Colombia, especially during the late 1990s when ratios of both revenues and expenditures to GDP rose. ${ }^{7}$ In Chile, in contrast, the relatively low level of budget rigidities, in tandem with ${ }^{7}$ High levels of budget rigidities do not always, however, lead to large
spending increases. In Argentina and Ecuador, for example, spending
increases were about average for the region, despite significant budget rigidities. its fiscal policy rule, have helped contain public spending increases in the face of rising revenues. ${ }^{8}$

Relatively small overall changes in spending-toGDP ratios mask the volatile and procyclical behaviour of real expenditures. Real spending growth in the past decade has varied considerably from year to year, and has tended to follow the economic cycle and growth of real revenues (figure 4). Real spending fell, for example, during the economic downturns in Argentina and the Bolivarian Republic of Venezuela early in the decade, but since then has rebounded markedly. While real spending increases were well contained across the region during 2003-2004, they have accelerated over the past two years, with outlays climbing by an average of $7.5 \%$ per annum. ${ }^{9}$ These increases have been somewhat higher among commodity exporters, but the expenditure boom

\footnotetext{
${ }^{8}$ See Alier (2007) for a discussion of budget rigidities in Argentina, Brazil, Chile and Ecuador.

9 For a further assessment of recent trends in real spending growth by country, see IMF (2006b).
} 
FIGURE 4

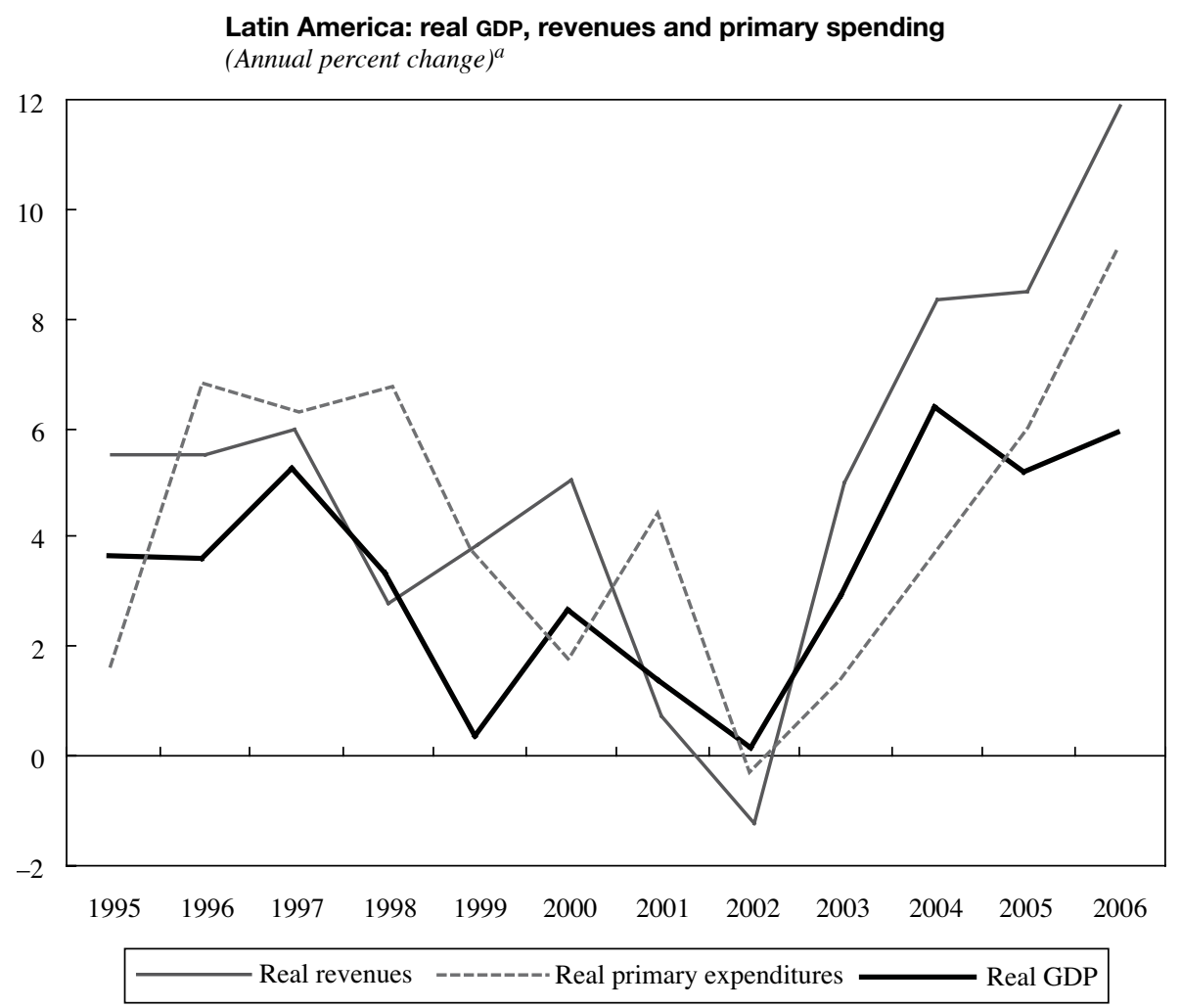

Source: Authors' calculations.

a Unweighted average of 17 countries. Based on the broadest definition of government available. Primary spending is defined as total spending net of interest payments.

has been a common phenomenon in the region, with 11 of the 17 countries increasing real public spending by $5 \%$ or more per annum in 2005-2006.

\section{(b) Trends in spending categories}

The trend toward rising spending/GDP ratios over the past 12 years is attributable to higher primary current outlays (figure 5). This spending rose by about three percentage points of GDP, owing to higher non-wage outlays. Wage bills rose in the late 1990s as a share of GDP, but have declined slightly in the current decade and are now roughly similar to what they were in the mid-1990s. ${ }^{10}$ As indicated below, rising social outlays, including social insurance benefits, appear to have accounted for the increase in current outlays. ${ }^{11}$

10 Based on figures for the wage bill from 1998 through 2006.

11 Based on social spending figures from ECLAC (2006a). Given that the coverage of these figures is restricted to central government in
Capital expenditures have tended to decline over time. These outlays hovered near $6 \%$ of GDP in the latter half of the 1990s, before falling nearly a percentage point of GDP through 2005-2006. As a result, the share of capital spending in total primary expenditures declined (figure 6).

Social expenditures rose from the mid-1990s through 2004. Social spending, broadly defined, grew by about two percentage points of GDP through 2002 and then reversed somewhat (figure 7). This growth occurred in all the countries covered in the sample, with the exception of Argentina and Ecuador. Higher spending for education and social insurance and assistance (including pensions) accounted for most of the increase. These outlays were mainly for current

some cases, the relationship between changes in total spending and social outlays should be assessed with caution. 
FIGURE 5

Latin America: Public sector expenditures

(As a percentage of gross domestic product $)^{a}$

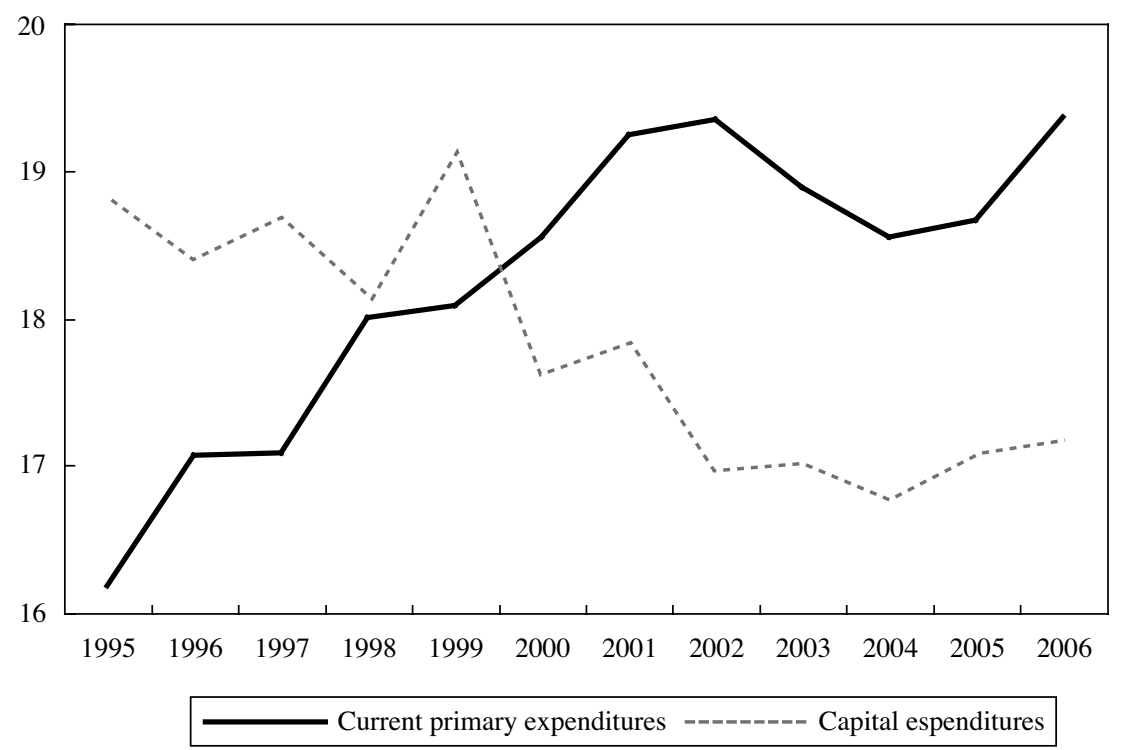

Source: Authors' calculations.

${ }^{\text {a }}$ Unweighted average of 17 countries. Based on the broadest definition of government available.

spending and tracked the increase in total current outlays during the period. Especially large increases in social spending (above six percentage points of GDP) were realized in Colombia, Bolivia and Honduras. In the case of the latter two countries, the Heavily Indebted Poor Countries (HIPC) Debt Initiative was a major catalyst for higher social spending from 1999 onward. In the case of Colombia and Bolivia, social security and assistance outlays accounted for more than half of the total increase, while in Honduras, education outlays were the main driver behind rising social expenditures.

In more recent years, social spending has fallen slightly as a ratio of GDP, although real outlays have risen substantially. Comprehensive data for 2005 or 2006 are only available for five countries (Chile, Colombia, Mexico, Peru and Uruguay). ${ }^{12}$ On average, social spending has fallen by about a fourth of a percentage point of GDP in these countries, as high economic growth has more than compensated for a substantial increase in real outlays.

\footnotetext{
${ }^{12}$ Based on national government figures and IMF estimates.
} 
FIGURE 6

Latin America: average public sector capital spending

(As a percentage of primary expenditures) ${ }^{a}$

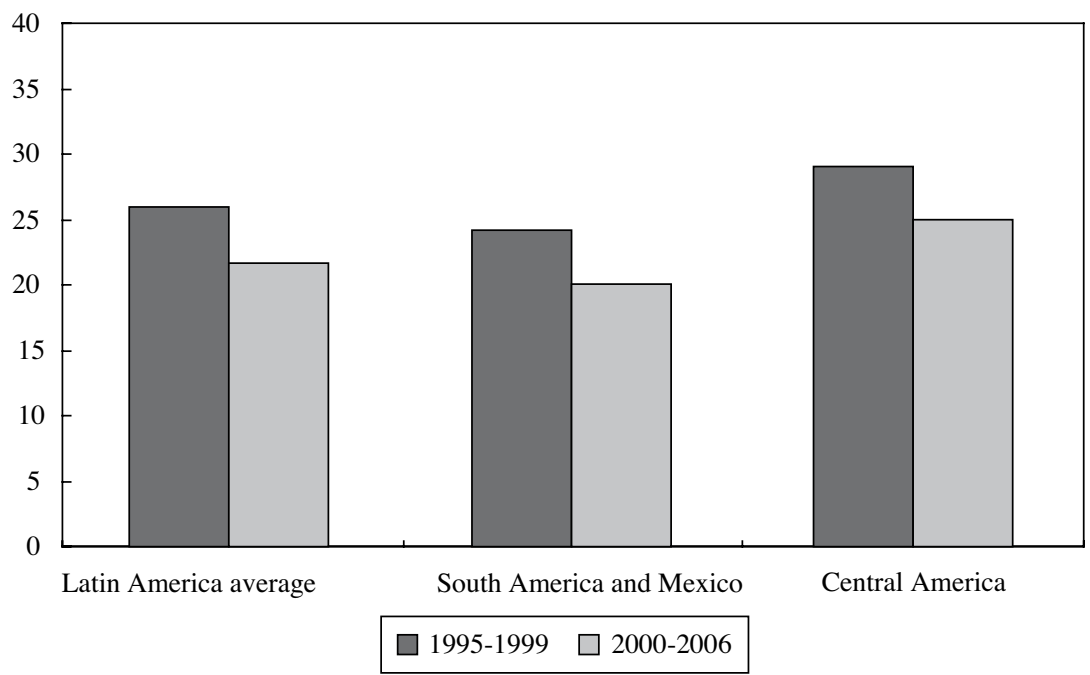

Source: Authors' calculations.

${ }^{a}$ Based on the broadest definition of government available.

FIGURE 7

Latin America: trends in social spending

(As a percentage of $G D P)^{a}$

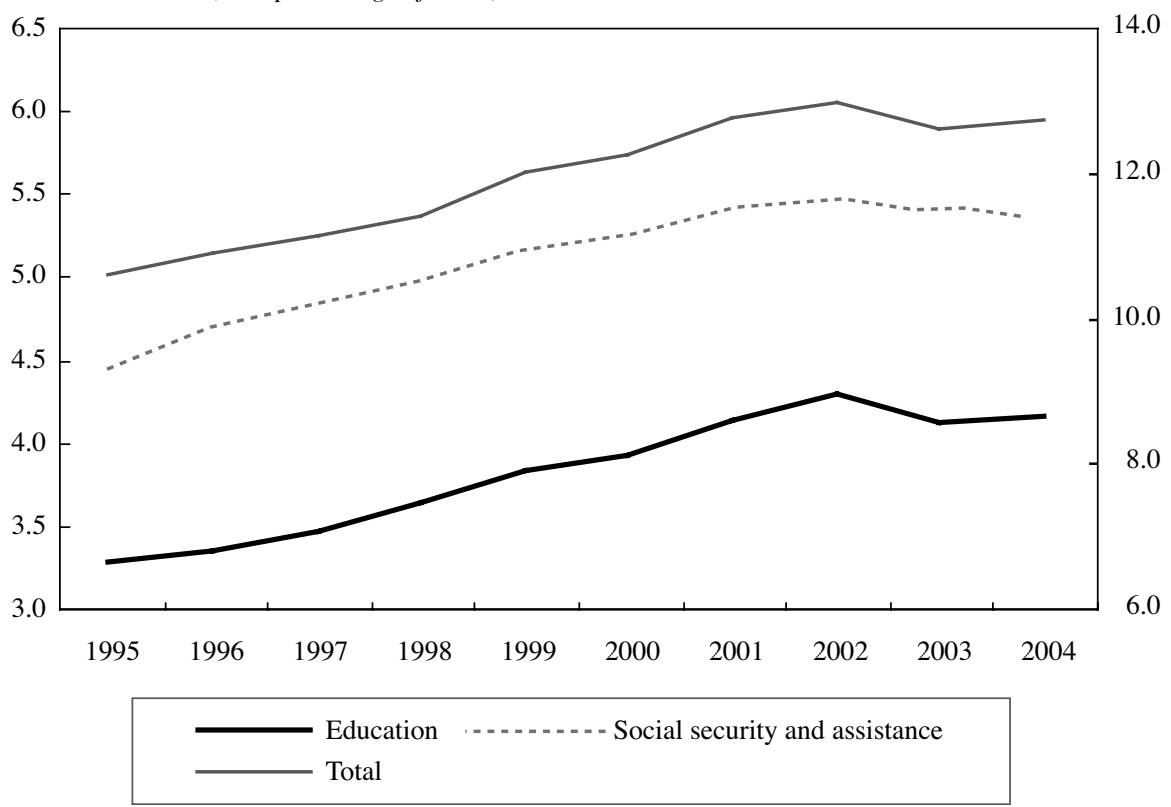

Sources: Social indicators and statistics database, ECLAC; data from national authorities and IMF estimates.

a Unweighted averages for 17 countries. For Bolivia, Chile, Colombia, Peru and Uruguay, 2004 data refer to 2003; for Argentina, 2004 data are based on information from its national government; for Honduras, 2002 and 2003 data are based on figures from 2001; and for Peru, data for 2002 through 2004 for education and social security refer to 2001 data. For Colombia and El Salvador, data were provided by their national authorities. 


\section{III}

\section{Key expenditure policy issues}

A comprehensive examination of the entire range of expenditure policy issues, including those related to public pension systems, would be outside the scope of this article. ${ }^{13}$ In what follows below, we provide an overview of some of the key issues that are central to the debate on how to implement more pro-growth, pro-poor expenditure policies in the region.

\section{Cyclicality of government spending}

Procyclical fiscal policy has precluded a more rapid decline of public debt and reduction of vulnerabilities during economic recoveries. A number of studies have delineated the region's propensity for procyclical expenditure policies. ${ }^{14}$ Spending trends in the recent recovery, notably the brisk acceleration of spending over the past two years, suggest that the region has not fully escaped its legacy of procyclical fiscal policy.

The cyclicality of spending varies across countries. Akitoby, Clements et al. (2006), for example, identify the short- and long-term relationship between real GDP growth and various categories of central government spending on a country-by-country basis. Their findings indicate that in about two thirds of Latin American countries, there is a statistically significant short-term relationship between GDP shocks and real primary expenditure, with spending and output moving procyclically - that is, in the same direction (table 1). ${ }^{15},{ }^{16}$ The results suggest that expenditure has been especially procyclical in Costa Rica, Guatemala and the Venezuela (Bolivarian Republic of). ${ }^{17}$

13 Recent works addressing this subject include Gill, Packard and Yermo (2005) and Roldos (2006).

${ }^{14}$ Among others, Gavin and Perotti (1997); Stein, Talvi and Grisanti (1998); Kaminsky, Reinhart and Végh (2004); Alesina and Tabellini (2005); Talvi and Végh (2005); Akitoby, Clements et al. (2006); Singh and Cerisola (2006); and Sahay and Goyal (2006).

15 This differs from the traditional approach to defining and measuring cyclicality, which assesses the cyclical position of the economy more than output shocks. See appendix A for further details.

16 The possible endogeneity between spending and output was examined by performing a Durbin-Wu-Hausman test, using the first lag of output growth as an instrument. The figures reported in table 1 exclude any results where, based on this test, endogeneity might be a concern.

17 See Kaminsky, Reinhart, and Végh (2004) and Sahay and Goyal (2006) for an assessment of the relationship between the growth of real spending and output by country.
The procyclical tendency of spending also varies across expenditure categories. Like Gavin and Perotti (1997), Akitoby, Clements et al. (2006) find that capital outlays appear to be the most procyclical. Excluding the extremely high estimate for Bolivia, the average coefficient for the statistically significant observations in table 1 is about 4.1 , implying that a $1 \%$ shock to output boosts capital spending by about $4 \%$. Spending on goods and services responds less markedly to shocks. Nevertheless, the average coefficient in most spending categories is higher than one for countries where there is a statistically significant relationship, indicating that spending responds more than proportionately to shocks. ${ }^{18}$

The cyclicality of spending is greater in the Latin American countries than in other developing countries. The share of countries where spending is procyclical is higher in Latin America than for developing countries as a whole (table 1), and average coefficient values are somewhat higher. Other studies also point to a more procyclical response of spending in Latin America. Singh and Cerisola (2006), for example, find that the correlation between the cyclical component of real spending and real GDP over the period 1990-2005 is much higher in Latin America than in Asia. Moreover, Gavin and Perotti (1997) find that government expenditure has been markedly more procyclical in Latin America than in industrialized countries.

There is no evidence that the reaction of expenditures to macroeconomic developments differs during economic upswings and downswings. Recent research has emphasized the asymmetrical behaviour of fiscal policy in developing countries (IMF, 2007). To assess the importance of this phenomenon in Latin America, the relationship between changes in output gaps and spending during good times (when output is above potential) and bad times (when output is below potential) was assessed on the basis of data on government spending, using the broadest definition of government available. The logarithm $(\log )$ of the terms of trade was also added to the model to capture the effects of changes in the external environment. Results were estimated with both

18 The average coefficient (including for those estimates that were statistically insignificant) was generally lower, but still exceeded 1.0 for primary spending, other goods and services, and capital outlays. 
Latin America: estimates of the short-run response of spending to gross domestic product (GDP) shocks

\begin{tabular}{|c|c|c|c|c|c|c|c|}
\hline & $\begin{array}{c}\text { Total } \\
\text { spending }\end{array}$ & $\begin{array}{l}\text { Primary } \\
\text { spending }\end{array}$ & $\begin{array}{l}\text { Current } \\
\text { spending }\end{array}$ & $\begin{array}{l}\text { Spending on } \\
\text { goods and } \\
\text { services }\end{array}$ & $\begin{array}{l}\text { Wages and } \\
\text { salaries }\end{array}$ & $\begin{array}{l}\text { Other goods } \\
\text { and services }\end{array}$ & $\begin{array}{l}\text { Capital } \\
\text { spending }\end{array}$ \\
\hline Argentina & 0.86 & $1.95^{\mathrm{b}}$ & $1.58^{c}$ & $1.54^{\mathrm{b}}$ & $1.33^{\mathrm{b}}$ & $1.81^{\mathrm{b}}$ & 2.32 \\
\hline Bolivia & 0.08 & 0.36 & -0.66 & -0.42 & -2.08 & 1.24 & $20.08^{c}$ \\
\hline Colombia & -0.98 & $\ldots$ & -1.23 & 0.64 & 0.74 & -0.63 & 0.63 \\
\hline Costa Rica & 1.60 & $2.13^{\mathrm{b}}$ & $1.44^{\mathrm{c}}$ & $1.15^{\mathrm{d}}$ & $1.82^{\mathrm{b}}$ & 0.71 & $2.62^{\mathrm{c}}$ \\
\hline El Salvador & 0.43 & 0.64 & 0.02 & 0.21 & -0.28 & 0.48 & 1.56 \\
\hline Guatemala & $2.77^{\mathrm{a}}$ & $2.78^{\mathrm{b}}$ & 1.00 & $1.82^{\mathrm{c}}$ & 0.27 & $\ldots$ & $5.95^{\mathrm{b}}$ \\
\hline Mexico & 0.66 & $2.09^{b}$ & 0.31 & $1.96^{\mathrm{b}}$ & $2.21^{\mathrm{b}}$ & $\ldots$ & $3.06^{\mathrm{b}}$ \\
\hline Nicaragua & 1.23 & 1.26 & 0.48 & -0.03 & 0.28 & $\ldots$ & $6.15^{\mathrm{b}}$ \\
\hline Paraguay & 0.59 & 0.61 & 0.34 & 0.62 & 0.19 & $1.65^{b}$ & 1.36 \\
\hline Peru & $0.66^{\mathrm{b}}$ & $1.15^{\mathrm{b}}$ & 0.51 & $1.44^{\mathrm{b}}$ & $0.82^{\mathrm{d}}$ & $2.04^{\mathrm{a}}$ & $1.83^{\mathrm{b}}$ \\
\hline Venezuela (Bol. Rep. of) & $2.30^{\mathrm{a}}$ & $2.68^{b}$ & $\ldots$ & $\ldots$ & $1.92^{\mathrm{b}}$ & 0.44 & $6.50^{\mathrm{b}}$ \\
\hline \multicolumn{8}{|l|}{ Memorandum items: } \\
\hline $\begin{array}{l}\text { Share of Latin American countries } \\
\text { with significant coefficient }\end{array}$ & 46.2 & 66.7 & 33.3 & 58.3 & 46.2 & 40.0 & 69.2 \\
\hline $\begin{array}{l}\text { Share significant for } 35 \text { other } \\
\text { developing countries }\end{array}$ & 31.3 & 40.0 & 40.0 & 48.4 & 28.1 & 31.0 & 45.2 \\
\hline $\begin{array}{l}\text { Average coefficient for } 35 \text { other } \\
\text { developing countries a, b, e }\end{array}$ & 1.18 & 1.75 & 1.03 & 1.59 & 1.20 & 2.86 & 1.38 \\
\hline
\end{tabular}

Source: Akitoby et al. (2006).

a Average of significant coefficients only.

b Significant at $1 \%$.

c Significant at 5\%;

d Significant at $10 \%$.

e Sample size for other developing countries ranges from 29 to 35 countries.

fixed effects and the generalized method of moments (GMM); the latter method is best suited to the context under study, given the presence of a lagged dependent variable and the potential endogeneity between output and spending. Table 2 indicates that the output gap has a statistically significant impact on spending. The estimates for the impact of negative and positive output gaps on spending-to-GDP ratios, however, are both insignificant, and thus provide no evidence of an asymmetrical effect of the cycle on spending. This finding differs from that of earlier research, which indicated that expenditures have been particularly procyclical during economic downturns in the region (Gavin and Perotti, 1997). In developing countries as a whole, in contrast, a recent study suggests that spending has typically been procyclical in good times but countercyclical in bad times (IMF, 2007).

Increases in spending-to-GDP ratios during the present economic recovery are somewhat lower than predicted by these econometric results. Strong growth in recent years has brought output close to potential in many countries and, as predicted by the model, has increased spending-to-GDP ratios. As suggested by the small size of the coefficients, the estimated effect of cyclical developments on spendingto-GDP ratios is modest. Given observed changes in output gaps (of about five percentage points, on average, for the 17 countries), the model predicts that spending ratios would rise by about 1.5 percentage points of GDP between 2003 and 2006, compared with the actual increase of half a percentage point. ${ }^{19}$ As noted earlier, the modest response of spending-to-GDP ratios to the economic cycle - both in the model and in recent out-turns - conceals the high rapid growth of government expenditures that has

19 Calculations are based on the GMM coefficient estimate of the relationship between the output gap and primary spending/GDP ratios (0.16). Changes in output gaps were estimated on the basis of changes in actual and potential output, with the latter estimated by a HodrickPrescott filter (see table 2). 
Latin America: response of expenditure of output gaps

\begin{tabular}{|c|c|c|c|c|}
\hline \multicolumn{5}{|c|}{ Dependent variable: primary expenditures to GDPa } \\
\hline & \multicolumn{2}{|c|}{ Fixed effects } & \multicolumn{2}{|c|}{ System GMM } \\
\hline Lagged dependent variable & $\begin{array}{c}0.63 \\
(12.31)^{b}\end{array}$ & $\begin{array}{c}0.63 \\
(12.28)^{b}\end{array}$ & $\begin{array}{c}0.86 \\
(6.98)^{b}\end{array}$ & $\begin{array}{c}0.82 \\
(5.41)^{b}\end{array}$ \\
\hline Output gap ${ }^{b}$ & $\begin{array}{c}0.09 \\
(2.40)^{c}\end{array}$ & & $\begin{array}{c}0.16 \\
(2.11)^{c}\end{array}$ & \\
\hline Log terms of trade & $\begin{array}{l}2.02 \\
(1.92)^{*}\end{array}$ & $\begin{array}{l}2.01 \\
(1.90)^{*}\end{array}$ & $\begin{array}{c}-0.21 \\
(0.19)\end{array}$ & $\begin{array}{c}0.36 \\
(0.18)\end{array}$ \\
\hline Lagged public debt to GDP & $\begin{array}{c}-0.003 \\
(0.84)\end{array}$ & $\begin{array}{c}-0.003 \\
(0.84)\end{array}$ & $\begin{array}{r}0.001 \\
(0.21)\end{array}$ & $\begin{array}{c}0.001 \\
(0.28)\end{array}$ \\
\hline Constant & $\begin{array}{c}-0.14 \\
(0.03)\end{array}$ & $\begin{array}{l}-0.05 \\
(0.01)\end{array}$ & $\begin{array}{c}4.23 \\
(0.83)\end{array}$ & $\begin{array}{c}2.43 \\
(0.23)\end{array}$ \\
\hline $\mathrm{R}^{2}$ & 0.86 & 0.86 & & \\
\hline Wald chi-square & & & 50.22 & 53.48 \\
\hline Hansen test & & & 11.23 & 10.11 \\
\hline P-value & & & 0.26 & 0.61 \\
\hline 2 nd order autocorrelation & & & -0.77 & -0.80 \\
\hline P-value & & & 0.44 & 0.42 \\
\hline Number of observations & 229 & 229 & 229 & 229 \\
\hline
\end{tabular}

Source: Authors' calculations.

a Absolute value of t-statistics (z-statistics for GMM results) in parentheses. $*$ Significant at $10 \%$; $^{* *}$ significant at $5 \%$; ${ }^{* * *}$ significant at $1 \%$. Z-statistics calculated using robust standard errors for the GMM results, using the two-step system GMM estimators in Stata (xtabond2). Period of estimation, 1989-2006. For some countries, data were not available for the entire time period. For the predetermined or endogenous variables (all variables except the terms of trade), only higher order lags were used (t-3, t-4 and t-5).

b Output gap defined as ((actual output - potential output)/potential output)*100. Potential output calculated using a Hodrick-Prescott filter for 1980-2010 data from the IMF World Economic Outlook database (http://www.imf.org/external/pubs/ft/weo/2006/01/data/index.htm).

accompanied high rates of economic growth in recent years. These rapid spending increases have slowed the decline in public debt during the present recovery.

\section{Public investment}

Public investment has been low relative to other developing regions, averaging between $5 \%$ and $6 \%$ of GDP in 1990-2006 - considerably less than the levels prevailing in Asia and Africa, but higher than in Central and Eastern Europe (table 3). Even after taking into account the significant participation of the private sector in infrastructure spending (two percentage points of GDP, according to the most recent available data), this spending still lags behind that of other regions. ${ }^{20}$ From

20 Based on data on infrastructure spending from the World Bank for seven countries (Argentina, Bolivia, Brazil, Colombia, Chile, Mexico and Peru) for 2000-2001. See appendix B for details. the late-1990s until recently, Latin American capital spending has tended to decline in relation to GDP. This decline in part reflected the wave of privatizations in the region during the 1990s, which have not, in practice, been fully offset by increased private investment in the affected sectors (Fay and Morrison, 2005). ${ }^{21}$ In other regions, public investment has risen or remained constant in relation to GDP.

Deficiencies in infrastructure - and the need for additional infrastructure investment - vary by country. As suggested in figure 8, the quality of infrastructure in

\footnotetext{
${ }^{21}$ The precise impact of privatization on public and private infrastructure investment in the region is difficult to quantify. In countries where public infrastructure investment declined between the mid-1990s and 2000-2001 (Argentina, Bolivia, Brazil and Mexico) - because of privatization or for other reasons - private investment in infrastructure failed to compensate fully for this decline. On average, overall public and private investment in infrastructure declined in these countries by close to one half of a percentage point of gdp during the second half of the 1990s.
} 
FIGURE 8

Latin America: institutional and infrastructural performance ${ }^{a}$

(As a percentage of the average standard deviation of the residuals) ${ }^{b}$
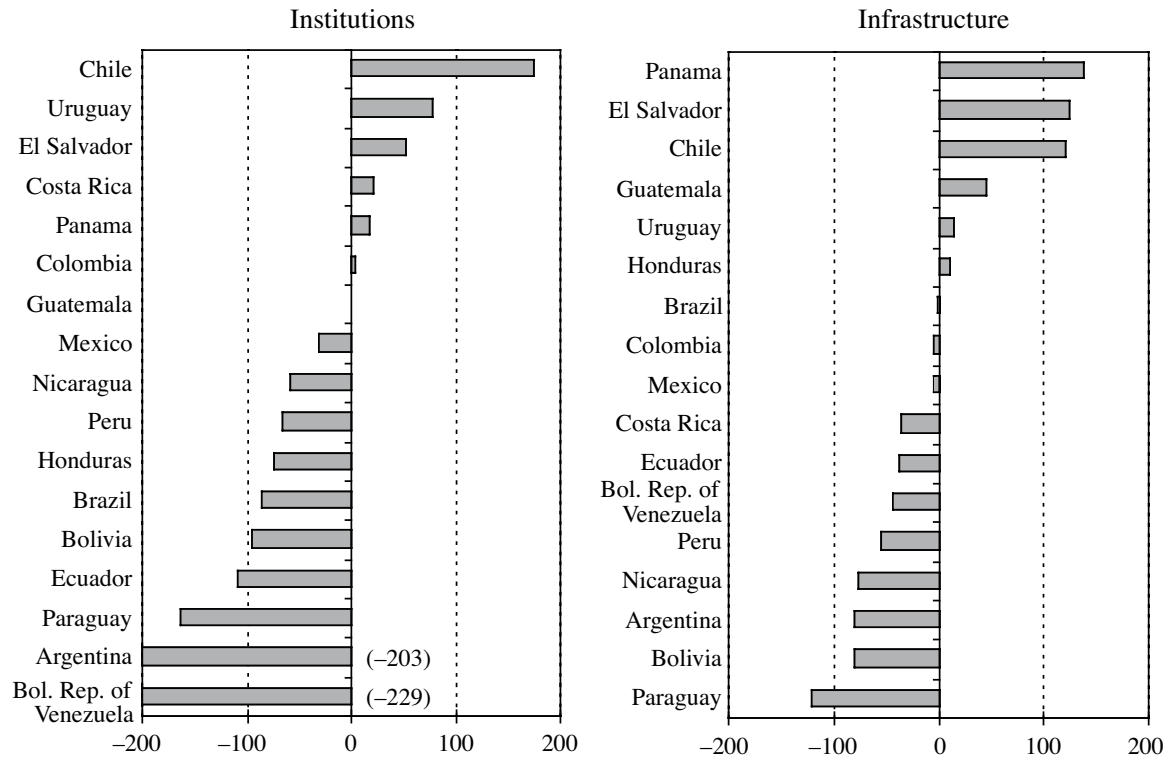

Source: Authors' calculations, based on López-Claros, Porter et al. (2006).

a Deviation of actual indices from values predicted by PPP - adjusted per capita income.

${ }^{\mathrm{b}}$ Residuals derived from a regression of the index score on institutions (infrastructure) and real GDP per capita in PPP terms for 125 countries.

TABLE 3

Latin America and other regions: public investment, 1995-2006

(As a percentage of gross domestic product)

\begin{tabular}{lrcc}
\hline & $1995-1999$ & $2000-2004$ & $2005-2006$ \\
\hline Latin America $^{\text {a }}$ & 5.8 & 5.1 & 5.1 \\
Africa & 7.6 & 7.4 & 8.0 \\
Asia & 8.6 & 8.4 & 8.6 \\
Central and & & & \\
Eastern Europe & 3.6 & 3.6 & 3.6 \\
\hline
\end{tabular}

Source: Authors' calculations, based on data from national authorities and the imf World Economic Outlook database.

a For Latin America, data cover 17 countries.

some countries in the region is higher than predicted by their level of economic development, notably in Chile, El Salvador and Panama. In Paraguay and Argentina, on the other hand, infrastructure lags are sizeable.
Inefficiencies in public investment are contributing to infrastructure lags. A non-parametric production function was employed to compare the efficiency of spending for seven countries (appendix B), which made it possible to analyse the relationship between spending and outcomes (in terms of improvements in infrastructure) across countries, and wide differences in performance were found. Using this approach, spending appears most efficient in Chile and Mexico, while in Bolivia and Colombia the returns from spending are much lower. In the case of Colombia, this result should be interpreted with caution, given that public investment may have been overstated in the national income accounts in the 1990s (which would tend, ceteris paribus, to lower efficiency scores); ${ }^{22}$ in a similar vein, recent improvements in the framework for managing public-private partnerships also suggest that the efficiency of infrastructure spending in

22 Public investment figures in the national income accounts have recently been revised downward for 2003 onward, owing to the overstatement of public investment by local governments. Revised data are not available for earlier years, but it is likely that spending was overestimated in those years as well. 


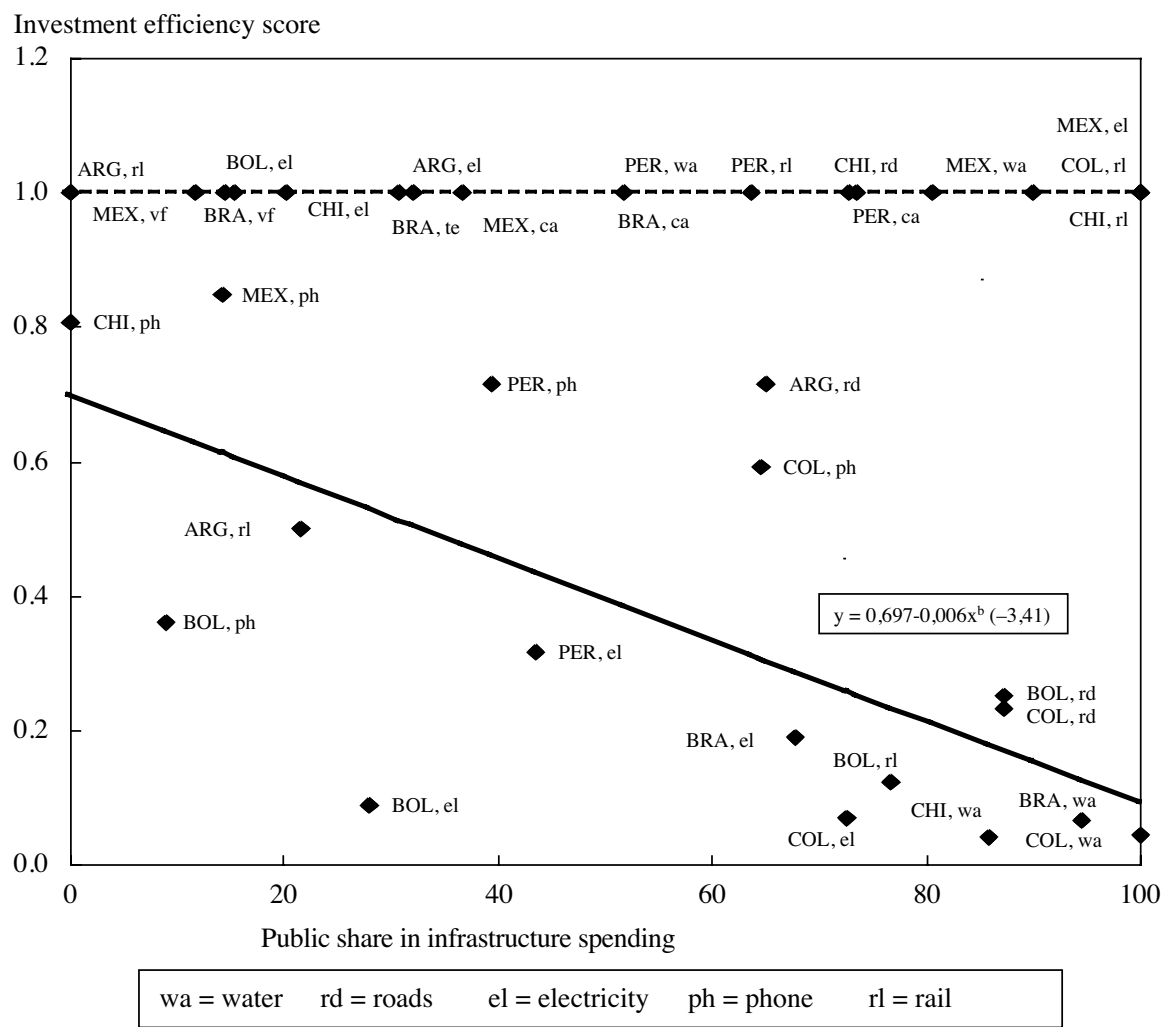

Source: Authors' calculations.

a Efficiency scores range from 1.0 (most efficient) to zero. Each observation represents a country's efficiency score in a given sector (electricity, railways, roads, telecommunications and water). See Appendix B for further details.

b Z-score in parentheses. Coefficients based on a truncated regression model with an upper bound of 1.0.

Colombia may be stronger than indicated by our results. Countries relying more heavily on the public sector for the provision of infrastructure services appear to be less efficient (figure 9), as do those where aggregate public infrastructure spending is relatively high. ${ }^{23}$

Weaknesses in public institutions and the volatility of capital spending also contribute to inefficiencies in investment spending. There is considerable scope to improve project selection and project appraisal in the region (IMF, 2005). More generally, figure 8 suggests that lags in institutional development are highly correlated with poor

\footnotetext{
${ }^{23}$ This also suggests that for countries where the share of the private sector has increased by more than the sample as a whole (Argentina, Chile, Colombia and Peru), the results may overestimate their present degree of inefficiency.
}

infrastructure. The volatility of capital spending may also contribute to inefficiencies if it leads to erratic cash flows to contractors and disrupts regular maintenance outlays (Fay and Morrison, 2005).

\section{Public sector employment}

Public sector wage bills are generally comparable to those in other regions. At the general government level, spending for public wages is similar to or lower than that of many other developing regions (table 4). ${ }^{24}$ However, there is wide variance in the level of spending

\footnotetext{
24 Data on general government wage bill outlays in developing countries are not widely available. Data for Guatemala and Panama refer to the central government only. In the case of Mexico, wages paid by public enterprises are included.
} 
Latin America and other regions: general government wages and salaries, 2004a

\begin{tabular}{lcccc}
\hline & $\begin{array}{c}\text { Wages, as a } \\
\text { percent of } \\
\text { GDP }\end{array}$ & $\begin{array}{c}\text { Wages, as a } \\
\text { percent of general } \\
\text { government } \\
\text { expenses }\end{array}$ & $\begin{array}{c}\text { Average central } \\
\text { government wage to } \\
\text { per capita GDP }\end{array}$ & $\begin{array}{c}\text { Ratio of public to } \\
\text { manufacturing sector } \\
\text { wages }\end{array}$ \\
\hline Latin America $^{\mathbf{b}}$ & $\mathbf{7 . 0}$ & $\mathbf{3 2 . 8}$ & $\mathbf{2 . 1}$ & $\mathbf{1 . 5}$ \\
Emerging Asia $^{\mathrm{d}}$ & 5.7 & 32.9 & 3.0 & 1.8 \\
Eastern Europe and Central Asia $^{\text {Middle East and North Africa }}$ & 7.9 & 23.6 & 1.3 & 0.6 \\
$\begin{array}{l}\text { Sub-Saharan Africa } \\
\text { Organisation for Economic }\end{array}$ & 10.6 & 41.9 & 3.4 & 1.0 \\
$\begin{array}{l}\text { Cooperation and Development } \\
\text { (OECD) }\end{array}$ & 9.6 & 30.8 & 5.7 & 2.0 \\
\hline
\end{tabular}

Source: Government Financial Statistics, IMF; World Bank database on government employment and wages; and Schiavo-Campo, de Tommaso and Mukherjee (1997).

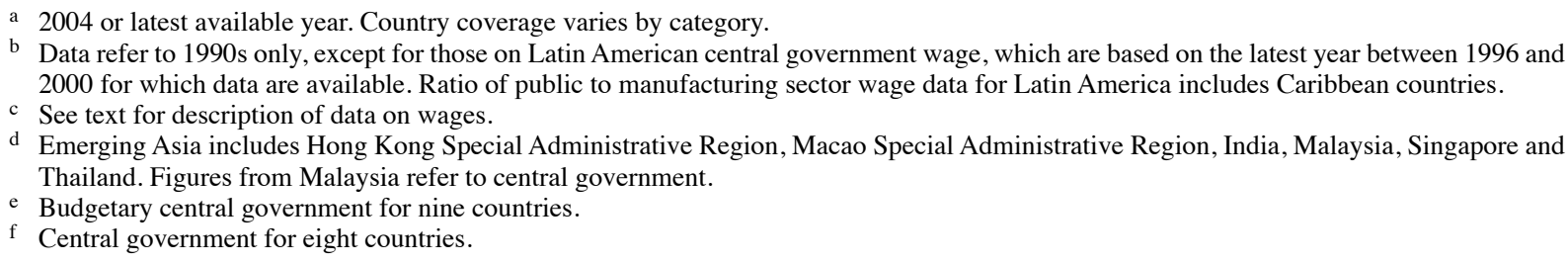

across the region, with spending in 2005 ranging from $4.5 \%$ of GDP in Nicaragua to $12.5 \%$ in Honduras, compared with the Latin American average of $7 \%$ in 2004-2005. The ratio of average public sector wages to wages in the manufacturing sector is also in line with other regions. And, while recent data are not readily available, figures from the 1990s suggest that public sector employment levels in Latin America are not particularly high (table 5).

The quality of government services in Latin America is lower than in many fast-growing regions of the world (table 6). The lower quality of services reflects, to a large extent, the region's less advanced level of development. On average, based on data from the International Country Risk Guide (ICRG) the quality of services in Latin America is in line with that predicted by income levels in the region (figure 10). At the same time, there are some important differences across countries. In particular, bureaucratic quality in Chile and Mexico is about $35 \%$ to $40 \%$ higher than predicted by income levels (more than one standard deviation above fitted values). In Paraguay and Venezuela (Bolivarian Republic of), on the other hand, the quality of the bureaucracy falls short of fitted values by more than one standard deviation. A recent assessment by the Inter-American Development Bank (IDB), reported in IDB (2005) and
Echebarría and Cortázar (2006), also indicates a wide variation in the quality of bureaucracies in the region; according to that assessment, in Brazil and Chile, the civil service is functioning well, but in over half of the countries of the region, systems are inadequate to attract qualified staff and ensure the efficient performance of employees.

The quality of government has not improved in Latin America since the late 1990s. The quality of services, as measured by the ICRG index of bureaucratic quality, increased steadily between 1990 and 1998, but has generally been flat thereafter (figure 11). After narrowing with respect to the levels prevailing in Eastern Europe and the Baltic States and Asia, differentials with these regions have remained broadly constant during this decade. The World Bank's measure of government effectiveness paints a more negative picture, with Latin America posting a decline in both absolute and relative terms between 1998 and 2005 (figure 12). This contrasts with the Eastern European and Baltic States, which, according to this index, have secured significant gains in government effectiveness.

While average wage bills are relatively modest in Latin America, the low and declining quality of public services suggests there is ample room to improve the efficiency of spending on public employment. 
Latin America and other regions: general government employment, 1990s a

\begin{tabular}{|c|c|c|c|c|}
\hline & $\begin{array}{c}\text { Number of } \\
\text { countries }\end{array}$ & $\begin{array}{c}\text { General } \\
\text { government } \\
\text { employment as } \\
\text { percentage of } \\
\text { population }\end{array}$ & $\begin{array}{c}\text { Number of } \\
\text { countries }\end{array}$ & $\begin{array}{c}\text { General government } \\
\text { employment as } \\
\text { percentage of total } \\
\text { employment }\end{array}$ \\
\hline Latin Americab $^{b}$ & 9 & 3.0 & 10 & 20.4 \\
\hline Asia & 11 & 2.6 & 3 & 17.2 \\
\hline Middle East and North Africa & 8 & 3.9 & 4 & 50.3 \\
\hline Sub-Saharan Africa & 20 & 2.0 & 8 & 28.4 \\
\hline Organisation for Economic Cooperation and & & & & \\
\hline Development (OECD) & 21 & 7.7 & 15 & 21.0 \\
\hline
\end{tabular}

Source: Schiavo-Campo, de Tommaso and Mukherjee (1997), Hammouya (1999) and OECD (2001).

a Latest data for 1990s, except for the figures on general government employment as a percentage of population, which are for the early 1990s.

b Includes Caribbean.

TABLE 6

Latin America and other regions: government effectiveness

\begin{tabular}{lcc}
\hline & $\begin{array}{c}\text { ICRG bureaucratic quality index } \\
(2005)^{\mathrm{a}}\end{array}$ & $\begin{array}{c}\text { World Bank measure of government } \\
\text { effectiveness (percentile ranking 2005) }\end{array}$ \\
\hline Latin America & $\mathbf{2 . 0}$ & $\mathbf{4 3 . 4}$ \\
Asia & 2.5 & 47.2 \\
Eastern Europe \& Baltics & 2.5 & 61.7 \\
Middle East and North Africa & 2.3 & 45.0 \\
Sub-Saharan Africa & 1.3 & 27.0 \\
Organisation for Economic Cooperation and & 3.7 & 88.0 \\
Development (OECD) & & \\
\hline
\end{tabular}

Source: Kaufmann, Kraay and Mastruzzi (2006) and the International Country Risk Guide (icrg) database.

a Index ranges in value from zero to a maximum value of four. Figure refers to value for ICRG index for bureaucratic quality, which is one of the 12 political risk components of the icrg rating system.

b Regional averages based on the percentile ranking for individual countries. The regional average for the oecd of $88 \%$, for example, indicates that the average measure of government effectiveness for an oecd country is better than $88 \%$ of all countries.

Improving the quality of the civil service is a complex task. Cross-country evidence suggests that increasing the generosity of average public sector pay is unlikely to be a solution unless it is accompanied by reforms that aim to establish merit-based bureaucracies and address the core weaknesses of administrations in the region. A cross-country regression of the determinants of government quality, for example, reveals that average wages have no statistically significant effect after controlling for per capita income. ${ }^{25}$ In addition, within Latin America, there is no statistically significant correlation between increases in the general government wage bill (as a share of GDP) and improvements in bureaucratic quality over the 1996-2005 period. Reform efforts should therefore centre on tackling the institutional weaknesses that plague a number of countries in the region, including patronage in hiring and promotions, the absence of performance evaluation and internal inequities in remuneration (i.e., different pay for similar jobs) (IDB, 2005; Echebarría and Cortázar, 2005).

\footnotetext{
25 Average wages were calculated using the average civil servant wage as a share of per capita GDP, as indicated in table 4. Details on these estimates are available from the authors upon request.
} 
FIGURE 10

\section{Latin America: per Capita GDP/bureaucratic quality ratio}

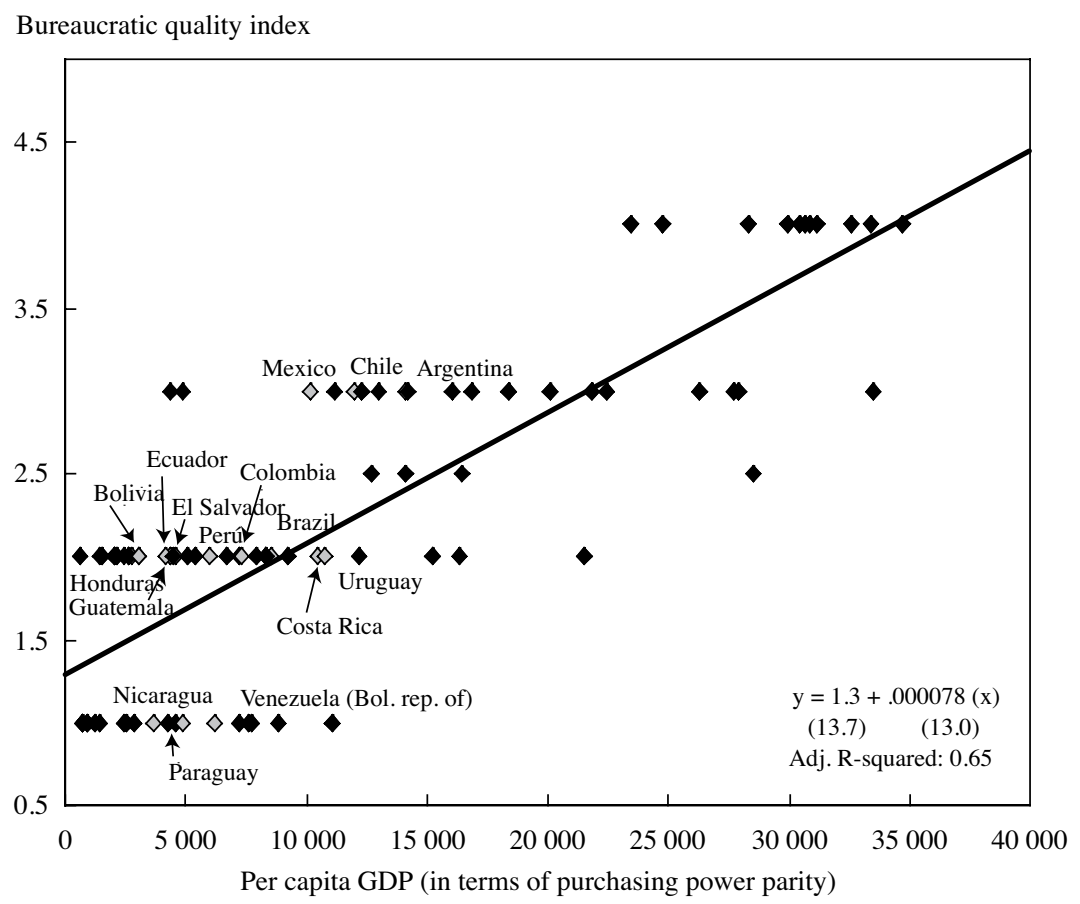

Source: Authors' calculations.

FIGURE 11

Latin America and other regions: quality of bureaucracy

(ICRG Index, 1990-2005)

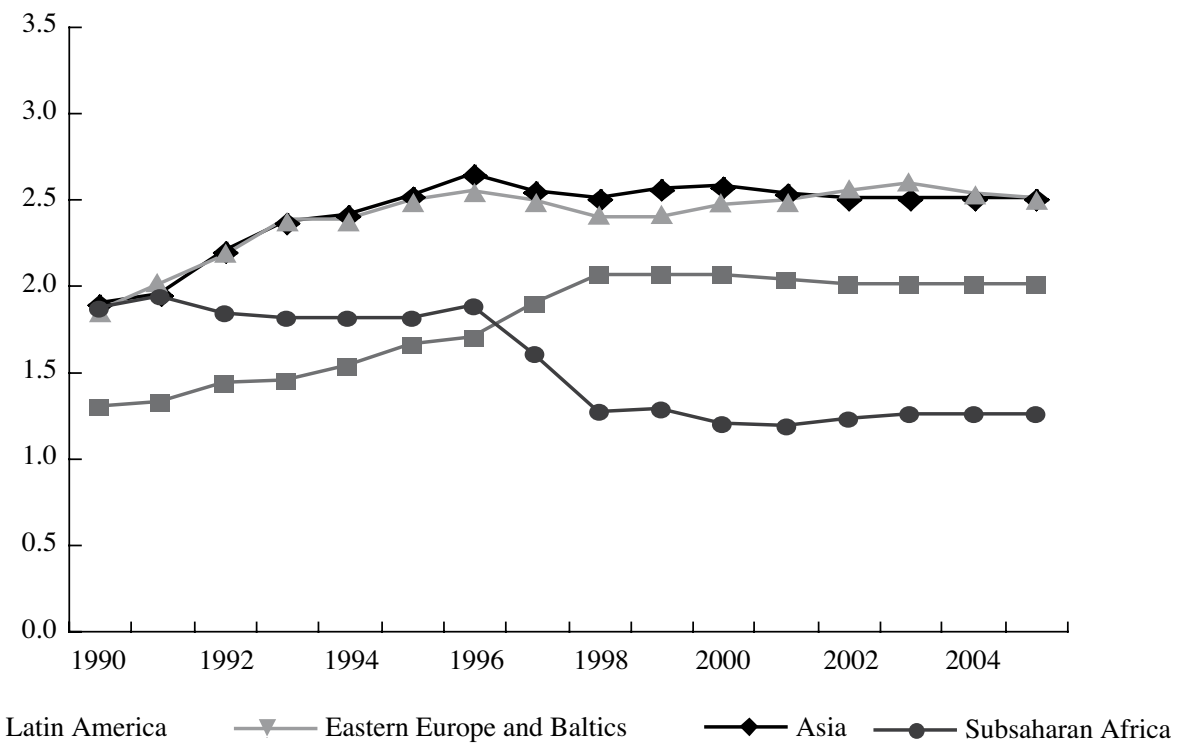

Source: The International Country Risk Guide (icrg) database. 
Latin America and other regions: government effectiveness, 1996-2005

(Percentile ranking)

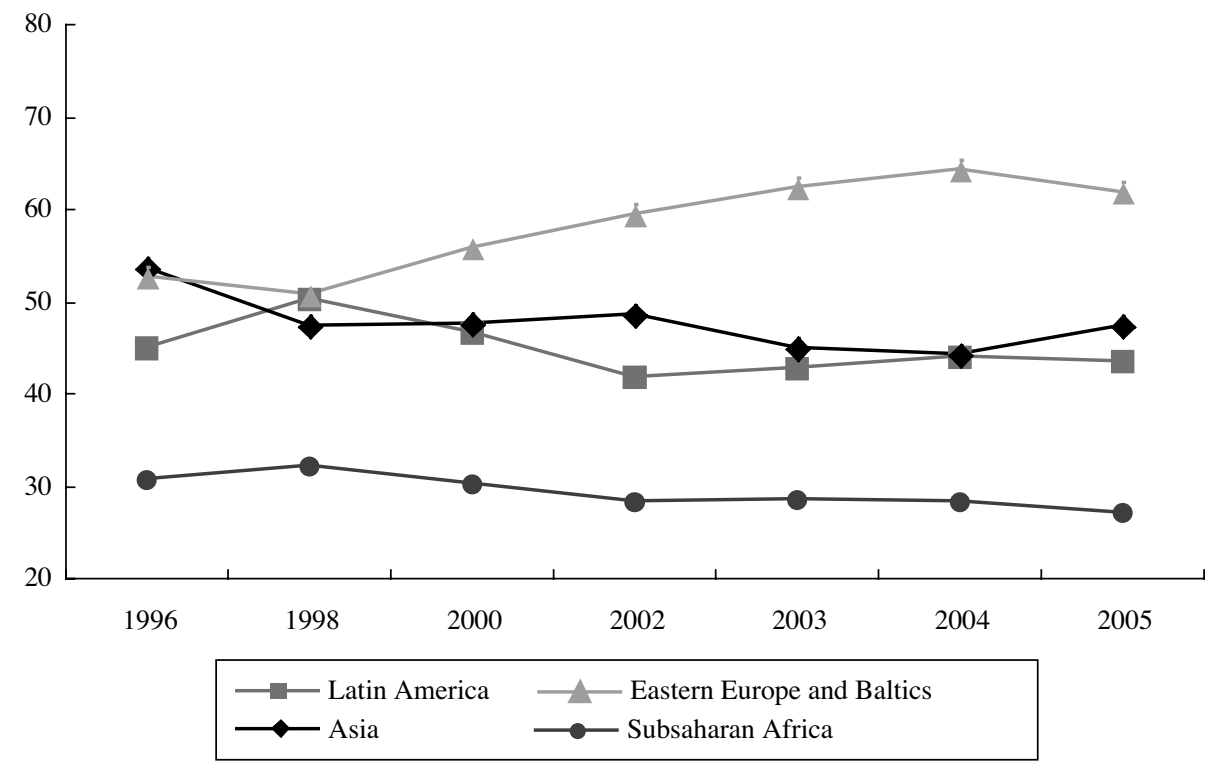

Source: Kaufmann, Kraay and Mastruzzi (2006).

\section{Social spending}

Social spending absorbs a large share of total government outlays. It represents almost $13 \%$ of GDP and half of primary government spending, ${ }^{26}$ and is higher than in the emerging economies of Asia, but lower than in the countries of the Organisation for Economic Co-operation and Development (OECD) and in Eastern Europe and Central Asia (table 7). The differences across country groups are largely explained by differences in their social protection spending, which mostly comprises pension benefits. $^{27}$

Substantial levels of social spending have coincided with mixed results on social indicators. The region's education and health indicators are broadly in line with its level of development (ECLAC, 2006a). Primary and secondary school enrolment rates have climbed since the 1990s, as have health indicators such as access to clean water, immunization rates and infant mortality rates.

\footnotetext{
26 Social spending comprises outlays for education, health, social protection (including both social insurance and social assistance programmes, such as school lunch programmes), housing and community amenities.

27 Comparisons across regions should be made with some caution, given the small sample size available for general government data. Central government data have been included in the comparator groups in table 7 in cases where social spending is highly centralized.
}

Nevertheless, Latin America exhibits significant lags in human capital relative to the industrialized countries and to the fast-growing regions. Net secondary school enrolment rates, for example, stand at around 60\%, compared with $70 \%$ in a sample of 28 emerging market and Caribbean countries.

Inefficiencies in public spending have retarded gains in social indicators. In the area of education, repetition rates - a common measure of inefficiency - are high relative to comparator countries. ${ }^{28}$ While relatively few Latin American countries have participated in international comparisons, education systems have fared poorly in international examinations assessing comprehension of science and mathematics, suggesting that the quality of education is weak in the region. ${ }^{29}$

The volatility of social spending may also be limiting its effectiveness. Social spending has been procyclical and even more volatile than aggregate spending (ECLAC,

28 Repetition rates are proxied by differences in gross and net secondary enrolment rates.

${ }^{29}$ For an examination of education in Latin America, see de Ferranti, Perry et al. (2003). See also OECD (2004) and Mullis, Martin et al. (2004a, 2004b) for information on the region's performance in international examinations. Herrera and Pang (2005) examine the efficiency of education and health spending in Latin America using a technique similar to the one used here to assess the efficiency of investment spending. 
Latin America and other regions: general government social spending, 2004 (As a percentage of $G D P)^{a}$

\begin{tabular}{|c|c|c|c|c|c|}
\hline & Education & Health & $\begin{array}{c}\text { Social } \\
\text { protection }\end{array}$ & $\begin{array}{l}\text { Housing and } \\
\text { community } \\
\text { amenities }\end{array}$ & total ${ }^{\mathrm{b}}$ \\
\hline Latin America ${ }^{c}$ & 4.2 & 2.6 & 5.4 & 0.9 & 12.7 \\
\hline Emerging Asia ${ }^{\mathrm{d}}$ & 3.5 & 1.3 & 2.2 & 1.1 & 8.4 \\
\hline Eastern Europe and Central Asia & 4.8 & 4.4 & 12.1 & 1.5 & 22.8 \\
\hline Middle East and North Africa ${ }^{\mathrm{e}}$ & 4.2 & 2.0 & 1.8 & 1.1 & 9.1 \\
\hline Sub-Saharan Africa ${ }^{\mathrm{f}}$ & 5.5 & 2.9 & 3.7 & 0.5 & 13.8 \\
\hline $\begin{array}{l}\text { Organisation for Economic Cooperation } \\
\text { and Development (OECD) }\end{array}$ & 6.4 & 6.9 & 17.3 & 0.8 & 32.6 \\
\hline
\end{tabular}

Source: Government Financial Statistics, imf; social indicators and statistics databases, eclac; data from national authorities; and imf estimates.

a Figures are for 2004 or latest available year.

b Number of observations vary by category. Therefore, the total social spending regional averages may not necessarily equal the sum of the regional averages of the spending components.

c Unweighted averages for 17 countries. Data for Bolivia, Chile, Colombia, Peru and Uruguay refer to 2003. Data for Argentina are based on figures from the national government and imf estimates. For Honduras, 2002 and 2003 data are based on figures for 2001, and for Peru, data for 2002 through 2004 for education and social security refer to 2001 data. For Colombia and El Salvador, data were provided by the national authorities.

d Emerging Asia includes Hong Kong Special Administrative Region, Macao Special Administrative Region, India, Republic of Korea, Singapore, Thailand and Vietnam. The figures for Republic of Korea and Thailand refer to central government.

e Budgetary central government for eight countries.

f Central government for seven countries.

2006a). This may also largely have impeded the efficiency of spending, as achieving substantial progress in health and education requires sustained effort over several decades (ECLAC, 2006b). Looking ahead, this suggests that further progress in reducing macroeconomic volatility will also be helpful in improving the efficiency of the public sector.

Despite high social spending, poverty rates remain high and are the region's most glaring developmental lag. At an estimated $41 \%$ of the population in 2005 , poverty exceeds the level predicted by the region's level of development (ECLAC, 2006a), owing to high levels of inequality in the distribution of income. On the basis of the most recent data available, Gini coefficients for the region average over 0.50 (see ECLAC, 2006a), compared with about 0.40 and 0.35 in Asia and the OECD, respectively, during the 1990s (de Ferranti, Perry et al., 2004). Other measures also confirm that inequality in Latin America is higher than in any other region of the world, with the possible exception of Sub-Saharan Africa (de Ferranti, Perry et al., 2004).

It appears that much of the region's social spending has been poorly targeted, limiting its benefits for the poor. On average, social spending has been regressive, with the poorest $20 \%$ receiving less than a fifth of the benefits of these outlays (table 8). Targeting has varied by country, with more progressive spending in Chile, Costa Rica and Uruguay, and a more regressive pattern of benefits in Bolivia, Peru and Nicaragua (eClac, 2006a). In practice, the distributive effect of this spending has been modest in most countries, although Argentina, Costa Rica and Brazil are exceptions to this rule (ECLAC, 2006a). Comparisons with other regions on the incidence of spending are difficult, given the small number of studies examining total social expenditures. ${ }^{30}$ Available evidence, however, suggests that education and health spending are even more regressive in other developing regions (Davoodi, Tiongson and Asawanuchit, 2003).

The distributive incidence of spending also varies significantly for different types of spending. A high share of the benefits from outlays on higher education and social insurance accrue to upper-income groups, while spending on primary education and social assistance mainly benefits the poor (de Ferranti, Perry et al., 2004; ECLAC, 2006a; Lindert, Skoufias and Shapiro, 2006).

\footnotetext{
${ }^{30}$ See Chu, Davoodi and Gupta (2000) for a discussion of the evidence on the targeting and progressivity of different types of social spending in developing countries.
} 
TABLE 8

Latin America: distribution of benefits from social spending to the richest and poorest quintiles $^{\mathrm{a}}$

(Percentages)

\begin{tabular}{lcc}
\hline & $\begin{array}{c}\text { Poorest } \\
\text { quintile }\end{array}$ & $\begin{array}{c}\text { Richest } \\
\text { quintile }\end{array}$ \\
\hline Education & 20.2 & 20.4 \\
Primary & 29.0 & 7.9 \\
Secondary & 13.2 & 18.3 \\
Tertiary & 1.9 & 52.1 \\
Health & 20.6 & 17.6 \\
Social protection & 5.6 & 51.2 \\
Total social spending & 15.0 & 30.4 \\
Memorandum item: & & \\
Share of quintiles & & \\
in primary income & 3.6 & 56.4 \\
\hline
\end{tabular}

Source: Authors' calculations, based on ECLAC (2006a).

a Unweighted average. Country coverage varies by category. For total spending, total education, health and social security spending, the number of countries covered is $8,13,14$ and 9 , respectively.
Targeted social assistance programmes have expanded in recent years and have shown promising results. These programmes often make cash assistance conditional on steps by recipients to send the children of the family to school or other actions that improve the prospects for escaping poverty on a long-term basis. Examples of these programmes include the Jefes y Jefas de Hogar and Familias programmes in Argentina, Bolsa Família in Brazil, Chile Solidario in Chile, Familias en Acción in Colombia and Oportunidades in Mexico. These conditional transfer programmes have been highly effective and well targeted (Lindert, Skoufias and Shapiro, 2006), and may prove helpful in achieving significant improvements in the well-being of the poor. In Brazil, for example, the expansion of the Bolsa Familia programme during 2003 and 2005 contributed to a narrowing of income gaps between the rich and poor and a reduction in poverty rates (Centro de Políticas Sociais, Fundação Getulio Vargas, 2006). In most countries, spending on these and other social assistance programmes remains modest (averaging about 1\%-1.5\% of GDP) and accounts for a small share of total social spending.

\section{IV}

\section{Summary and policy implications}

Primary expenditures have trended upward since the mid-1990s, driven by increases in current spending. The increase in spending has been the result of non-wage outlays, including spending for social protection. At the same time, capital expenditures have remained at low levels in most years. Public investment remains low relative to most developing regions of the world.

There is substantial scope to improve the efficiency of government expenditure. The ability of countries to translate spending on public investment into tangible gains in the provision of infrastructure varies markedly across countries. This suggests that large efficiency gains are possible by adopting the best practices of the most efficient countries of the region. Greater reliance on the private sector for the provision of infrastructure could also boost efficiency in some cases, although this may also require a strengthening of the institutional framework for private investment
(IMF, 2005, 2006a). ${ }^{31}$ The region's lacklustre ratings on institutional quality and government services also suggest opportunities to improve the efficiency of spending on government employment. Countries with high wage bills as a share of GDP do not necessarily enjoy better government services, suggesting that higher wages are unlikely, by themselves, to lead to better government services. Inefficiencies are also manifest in social spending, as the education system in many countries is characterized by high rates of repetition and, in some countries, poor performance on international examinations.

\footnotetext{
31 A strong institutional framework is also required to ensure that the fiscal risks of public-private partnerships are adequately managed and that these partnerships are driven by efficiency considerations, rather than a desire to bypass normal budgetary procedures. See IMF (2006a).
} 
The region's recent experience suggests a clear road map for forging a more pro-poor pattern of social spending. The region continues to suffer high rates of income poverty and high rates of underlying income inequality. Social spending has done relatively little to alleviate this inequality, as most social spending is regressive. The share of spending accruing to the poorest $20 \%$ of households varies markedly by spending category, however. Some spending is fairly well targeted, such as outlays for primary education and social assistance programmes, while other spending, such as that for higher education and social protection, provides only modest benefits for the poor. In the light of this reality, options for achieving a more pro-poor pattern of spending include the continued reform of public social protection schemes to reduce their generosity and place them on an actuarially sound footing (thus reducing their share of social spending over the longer term); increased user fees for higher education (combined with subsidies for lowincome families to ensure their access); improvement of the quality of secondary education to reduce secondary school repetition rates; and expansion of targeted social assistance programmes.

Addressing the procyclical tendencies of spending remains a challenge for Latin America. After being well contained in the early phases of the present economic recovery, the growth of real spending accelerated in 2005-2006, in line with the region's legacy of procyclical fiscal policy. Reducing the procyclicality of expenditure will require a further strengthening of political resolve to limit spending growth during good times. In this context, explicit ceilings for expenditure growth, while leaving the automatic stabilizers on the revenue side free to operate, could be helpful, including as a means of signalling government commitment to fiscal discipline (see Debrun and Kumar, 2006 and IMF, 2007). Indeed, numerical restrictions on fiscal variables (which include fiscal rules for the growth of expenditures, deficits and debt) have been associated with better fiscal performance in the region (Filc and Scartascini, 2006). At the same time, compliance with such rules - including expenditure rules - has been uneven. This underscores the need for well-designed sanctions and political commitment to make them effective. Beyond expenditure rules, the reduction of public debt to prudent levels would also help curb procyclicality by reducing the probability of macroeconomic crises and the need for sharp fiscal contractions to restore debt sustainability and market confidence. Further improvements in the structure of debt - including the lengthening of maturities and greater reliance on debt issued in domestic currency - could also help to obviate the need for contractionary expenditure policies during economic downturns (IADB, 2006 and IMF, 2007).

Reducing the volatility of expenditures could also enhance their efficiency. The stop-and-go nature of capital expenditures may be contributing to the inefficiency of these outlays. In a similar vein, more stable and predictable growth of outlays in the social sectors would facilitate progress in implementing health and education programmes.

APPENDIX A

\section{Econometric methodology used to assess the cyclicality of spending}

Table 1 reports on the country estimates on the short-run elasticity of spending with respect to output, from Akitoby, Clements et al. (2006). These authors estimate the following error-correction model to assess the relationship between central government spending on category $i\left(\mathrm{G}_{\mathrm{i}}\right)$ and real output $(Y)$ for a given country:

(1) $\Delta \log G_{i t}=\mu+\beta_{0} \Delta \log Y_{t}+\gamma\left[\log G_{i, t-1}-\delta \log Y_{t-1}\right]+\varepsilon_{t}$

where $\beta_{0} \Delta \log Y_{t}$ captures the impact of changes in output on spending in the short run. The coefficient $\beta_{0}$ measures the short-run elasticity of government spending with respect to output. These coefficients, estimated separately for different categories of expenditure $(G)$, are reported in table 1 .

The second term, $\gamma\left[\log G_{i, t-1}-\delta \log Y_{t-1}\right]$, measures an error-correction term and the movement of spending back to its long-run equilibrium. In this term, $\delta$ indicates the long-run elasticity of government spending with respect to output, and $\gamma$ (if negative) is the rate at which government spending adjusts to past disequilibrium.

Estimates for Table 2 follow a modified version of IMF (2007) and Balassone and Francese (2004). To estimate the impact of changes in the output gap on government expenditure $(\varepsilon)$, a regression is estimated for the following equation:

$$
g_{t}=\alpha_{0}+\beta_{1} g_{t-1}+\beta_{2} c_{t}+\beta_{3} d_{t-1}+\varepsilon o_{t}+v_{t}
$$


where $g$ is the ratio of primary expenditures to GDP; $c$ is the $\log$ of the terms of trade; $d$ is the public debt-to-GDP ratio; and $o$ is the output gap ((actual GDP-potential GDP)/potential GDP)*100. This specification is fairly standard in the literature, although not all authors have included a variable to capture terms of trade effects, and most studies have focused on total (rather than primary) spending.

To test for the asymmetric reaction of government spending to positive and negative output gaps, the estimating equation is modified to:
(3) $g_{t}=\alpha_{0}+\beta_{1} g_{t-1}+\beta_{2} c_{t}+\beta_{3} d_{t-1}+\varepsilon_{P} o_{t}^{P}+\varepsilon_{N} o_{t}^{N}+v_{t}$

where $\varepsilon_{P} \neq \varepsilon_{N}$ and the suffixes $P$ and $N$ indicate whether the coefficient applies to positive $\left(o_{t}^{P}\right)$ or negative $\left(o_{t}^{N}\right)$ output gaps. When the observation for the output gap is positive, for example, $o_{t}^{P}$ equals the observed value of the output gap; when the output gap is negative, $o_{t}^{P}$ is zero.

APPENDIX B

\section{The efficiency of public investment in Latin America}

\section{Methodology}

Following the approach used in a number of studies (e.g., Gupta and Verhoeven, 2001; Clements, 2002; Herrera and Pang, 2005), the efficiency of public spending can be assessed by relating public outputs to the spending that was allocated to achieve them. In the present context, this is done by evaluating the relationship between public investment and infrastructure outputs.

Using a non-parametric technique (Free Disposable Hull Analysis, or $\mathrm{FDH}$ ), a production function linking spending inputs and infrastructure outputs is estimated. FDH efficiency analysis first identifies efficient countries, that is, those countries that produce more outputs compared to other countries that spend as much or more. Those countries are assigned an efficiency score of 1 . Then, for the countries that are less efficient, an efficiency score is derived by taking the ratio of spending of the efficient country (E) and spending of the less efficient country

(A), that is $\varepsilon_{\text {input }}(\mathrm{A})=\operatorname{spending}(\mathrm{E}) /$ spending $(\mathrm{A})$

(this is the input efficiency score of the less efficient country - the output efficiency score is given by output in country A over that of country E). This efficiency score is, by construction, less than 1 . The input efficiency score can be interpreted as the minimum level of spending that other countries have needed to achieve the same or a higher level of infrastructure outputs, expressed as a share of actual investment spending. In the narrow interpretation of efficiency outlined below, this implies that the maximum savings from efficiency enhancement are 1 minus the input efficiency score.

FDH provides a powerful tool for ranking countries by level of efficiency, but caution is needed in interpreting the results. FDH provides several advantages: it is not an econometric exercise and does not require imposing specific functional forms on the efficient frontier. However, FDH does assume that the chosen input and output variable are related through a production process. Narrowly interpreted,
FDH measures technical efficiency - but this assumes that the right inputs and outputs have been identified, and that countries all have access to the same production technology. Less narrowly interpreted, FDH provides an assessment of how countries compare in how much they spend and the policy objectives they pursue with this spending. Apart from technical inefficiency, there can be a wide variety of reasons for why efficiency varies, including varying production technologies, differences in policy objectives, and the impact of unidentified inputs and exogenous factors (for example, geography would impact the efficiency of spending on roads, as a mountainous country would spend more per kilometre while still operating at maximum technical efficiency). In addition, the efficiency scores from FDH analysis are highly sensitive to country sample selection and measurement error. Finally, in the present context, some caution is required in interpreting the rankings as a yardstick of the current degree of efficiency in spending, given that the exercise is largely based on data through 2001, the most recent available on a disaggregated, cross-country basis.

A particular issue in the case of infrastructure spending in Latin America is that the private sector undertakes a sizeable share of infrastructure investment (see appendix B, table B.1). Therefore, it is not possible to establish a strict relationship between public spending and output indicators. A second best alternative - adopted for this study - is to assess the relationship between total spending (including by the private sector) and outputs. In addition, an adjusted measure is computed, based on a correction for the impact of private-sector participation on the efficiency rankings. ${ }^{32}$

\footnotetext{
32 This is done in two steps: first, running a truncated regression assessing the relationship between efficiency and the private-sector share across all countries; second, estimating the corrected efficiency score for the sector on the basis of this regression and the share of the private sector in that country relative to other countries. This implies a downward adjustment on the efficiency scores for countries with a high level of private-sector participation.
} 
TABLE B.1

Latin America: infrastructure spending, 1991-2001'a

(Averages, as a percentage of GDP)

\begin{tabular}{lccc}
\hline Country & $\begin{array}{c}\text { Total } \\
\text { spending }\end{array}$ & $\begin{array}{c}\text { Public } \\
\text { spending }\end{array}$ & $\begin{array}{c}\text { Private } \\
\text { spending }\end{array}$ \\
\hline Argentina & 1.5 & 0.4 & 1.2 \\
Bolivia & 7.4 & 3.2 & 4.2 \\
Brazil & 2.4 & 1.3 & 1.1 \\
Chile & 4.6 & 1.6 & 3.0 \\
Colombia & 5.0 & 3.5 & 1.5 \\
Mexico & 1.7 & 0.6 & 1.1 \\
Peru & 1.7 & 0.6 & 1.1 \\
\hline
\end{tabular}

Source: Authors' calculations.

a Includes spending on railways, roads, electricity, water and telecommunications.

\section{Data}

The efficiency analysis is carried out on data for the 1990s and early 2000s for a set of seven Latin American countries (Argentina, Bolivia, Brazil, Chile, Colombia, Mexico and Peru) and five infrastructure sectors (railways, roads, electricity, water and telecommunications). Data on public and private infrastructure spending by sector comes from Calderón and Servén (2004), with updates also provided by Luis Andres of the World Bank (table B.1).

The change in the stock of infrastructure is based on the World Bank's World Development Indicators database. Table B. 2 presents annual percentage improvements in infrastructure outcomes. The figures indicate that improvements

TABLE B. 2

Latin America: infrastructure improvements, 1990s and early 2000s

(Average annual change, in percent)

\begin{tabular}{|c|c|c|c|c|c|c|c|c|}
\hline Country & $\begin{array}{c}\text { Rail lines } \\
\text { (km/1000 } \\
\text { capita) }\end{array}$ & $\begin{array}{l}\text { Roads } \\
\text { (metres/ } \\
\text { capita) }\end{array}$ & $\begin{array}{c}\text { Paved } \\
\text { roads } \\
\text { (metres/ } \\
\text { capita) }\end{array}$ & $\begin{array}{c}\text { Electricity } \\
\text { losses } \\
\text { (\% of total } \\
\text { output)a }\end{array}$ & $\begin{array}{l}\text { Electricity } \\
\text { access by } \\
\text { households } \\
\text { (\% of total } \\
\text { pop) }\end{array}$ & $\begin{array}{c}\text { Electric } \\
\text { power } \\
\text { consumption } \\
\text { (kWh per } \\
\text { capita) }\end{array}$ & $\begin{array}{c}\text { Water } \\
\text { access } \\
\text { (\% of total } \\
\text { pop) }\end{array}$ & $\begin{array}{c}\text { Main tele- } \\
\text { phone lines } \\
\text { (per } 1000 \\
\text { workers) }\end{array}$ \\
\hline & $1990-2002$ & $\begin{array}{l}1992- \\
1999\end{array}$ & 1992-1999 & 1991-2002 & Latest data ${ }^{\mathrm{b}}$ & $\begin{array}{l}\text { Early } 1990 \mathrm{~s} \\
\text { - early } 2000 \mathrm{~s}^{\mathrm{c}}\end{array}$ & $1990-2002$ & 1991-2002 \\
\hline Argentina & -0.76 & -1.18 & -0.77 & -0.81 & $\ldots$ & 5.77 & $\ldots$ & 10.55 \\
\hline Bolivia & -1.92 & -0.10 & 7.33 & -0.66 & 2.77 & 4.83 & 1.50 & 11.64 \\
\hline Brazil & -0.48 & -0.92 & -5.58 & 0.79 & 6.29 & 2.61 & 0.60 & 20.63 \\
\hline Chile & -6.28 & -1.53 & 3.18 & -4.26 & $\ldots$ & 10.21 & 0.46 & 16.30 \\
\hline Colombia & 0.01 & -1.08 & 1.69 & -0.71 & 0.59 & 0.04 & 0.00 & 12.88 \\
\hline Mexico & 0.68 & 2.98 & 1.66 & 1.32 & $\ldots$ & 4.85 & 1.15 & 9.91 \\
\hline Peru & 0.59 & 0.39 & 4.29 & -0.47 & -0.14 & 4.19 & 0.79 & 14.03 \\
\hline
\end{tabular}

Source: Authors' calculations.

a A decline in efficiency losses implies an improvement in the efficiency of electricity distribution.

b The improvement is calculated based on the difference between the last year and the earliest year in the 1990s for which data are available.

c Improvement in average use 1991-1993 to 1999-2002.

TABLE B.3

Latin America: aggregated public efficiency scores

\begin{tabular}{|c|c|c|c|c|c|c|}
\hline Country & $\begin{array}{c}\text { Public } \\
\text { efficiency }\end{array}$ & Rank & $\begin{array}{l}\text { Level of public } \\
\text { efficiency }\end{array}$ & $\begin{array}{l}\text { Adjusted public } \\
\text { efficiency }^{\mathrm{b}}\end{array}$ & Adjusted rank & $\begin{array}{c}\text { Adjusted level } \\
\text { of public } \\
\text { efficiency }\end{array}$ \\
\hline Mexico & 0.974 & 1 & High & 0.824 & 1 & High \\
\hline Argentina & 0.804 & 2 & High & 0.530 & 4 & Medium \\
\hline Chile & 0.802 & 3 & High & 0.732 & 2 & High \\
\hline Peru & 0.655 & 4 & Medium & 0.598 & 3 & Medium \\
\hline Brazil & 0.410 & 5 & Medium & 0.432 & 5 & Medium \\
\hline Bolivia & 0.218 & 6 & Low & 0.036 & 7 & Low \\
\hline Colombia & 0.202 & 7 & Low & 0.253 & 6 & Low \\
\hline
\end{tabular}

Source: Authors' calculations.

a Efficiency in each sector aggregated using the share of public investment in each applicable sector.

b Adjusted by the effect of private-sector spending on the efficiency score in each sector. 
in infrastructure have varied widely by country and sector, with the most noteworthy gains in roads, electricity and telephones achieved by Chile. The results also suggest that countries with relatively high levels of spending (e.g., Bolivia and Colombia) have not achieved the most rapid progress.

\section{Results}

Table B. 3 presents the results of the FDH analysis. The results are based on an aggregation of the efficiency scores matching spending and outputs in railways, roads, electricity, water and telecommunications. Each sector was weighted by its share in public sector investment spending. The results reveal a large amount of inefficiency, given the significant difference from the efficiency frontier (i.e., an efficiency score of 1.0) in many countries. Inefficiencies are especially noteworthy in Bolivia and Colombia, while Chile and Mexico are among the most efficient countries. ${ }^{33}$ In the case of Chile, the high level of efficiency is due to its substantial progress in improving infrastructure indicators, while in the case of Mexico, high efficiency is attributable to continued progress of output indicators in conjunction with low levels of expenditures. The adjustment of the efficiency scores for differing levels of private-sector participation has little effect on the country rankings.

(Original: English)

Bibliography

Akitoby, Bernardin, Benedict Clements and others (2006): Public spending, voracity, and Wagner's Law in developing countries, European Journal of Political Economy, vol. 22, Amsterdam, Elsevier.

Alesina, Alberto and Guido Tabellini (2005): Why Is Fiscal Policy So Often Procyclical?, NBER Working Paper, No. 11600, Cambridge, Massachusetts, National Bureau of Economic Research.

Alier, Max (2007): Measuring Budget Rigidities in Latin America, IMF Working Paper, Washington, D.C., International Monetary Fund, forthcoming.

Balassone, Fabrizio and Maura Francese (2004): Cyclical asymmetry in fiscal policy, debt accumulation, and the Treaty of Maastricht, Temi di discussione, No. 531, Rome, Banca d'Italia, December.

BID (Banco Interamericano de Desarrollo) (2005): The Politics of Policies, Washington, D.C.

(2006): Living With Debt: How to Limit the Risks of Sovereign Debt, Washington, D.C.

Calderón, César and Luis Servén (2004): Trends in Infrastructure in Latin America, World Bank Policy Research Paper, No. 3401, Washington, D.C., World Bank.

Centro de Políticas Sociais, Fundação Getulio Vargas (2006): Poverty, inequality, and stability: the second real. Available in http://www. fgv.br/cps/pesquisas/site_ret_eng/.

Clements, Benedict (2002): How efficient is education spending in Europe?, European Review of Economics and Finance, vol. 1, Lisbon, Centro de Investigação sobre Economía Financeira.

Clements, Benedict, Sanjeev Gupta and Gabriela Inchauste (2004): Fiscal policy for development: an overview, in S. Gupta, B. Clements and G. Inchauste (eds.), Helping Countries Develop: The Role of Fiscal Policy, Washington, D.C., International Monetary Fund.

Chu, Ke-young, Hamid Davoodi and Sanjeev Gupta (2000): Income Distribution and Tax, and Government Social Spending Policies in Developing Countries, WIDER Working Paper, No. 214, Helsinki, World Institute for Development Economics Research.

Davoodi, Hamid, Erwin Tiongson and Sawitree Asawanuchit (2003): How Useful Are Benefit Incidence Analyses of Public Education and Health Spending?, IMF Working Paper, No. 03/227, Washington, D.C., International Monetary Fund.

Debrun, Xavier and Manmohan Kumar (2006): The DisciplineEnhancing Role of Fiscal Institutions: Theory and Empirical
Evidence, document presented at the Workshop "The Role of Fiscal Rules and Institutions in Shaping Budgetary Outcomes", Brussels, November.

De Ferranti, David, Guillermo Perry and others (2003): Closing the Gap in Education and Technology, Washington, D.C., World Bank. (2004): Inequality in Latin America: Breaking with History?, Washington, D.C., World Bank.

Echebarría, Koldo and Juan Cortázar (2006): Public administration and public employment reform in Latin America, in Eduardo Lora (ed.), The State of State Reform in Latin America, Washington, D.C., Inter-American Development Bank.

ECLAC (Economic Commission for Latin America and the Caribbean) (2006a): Social Panorama of Latin America, LC/G.2326-P, Santiago, Chile. United Nations publication, Sales No. E.06.II.G.133. (2006b): Shaping the Future of Social Protection: Access, Financing and Solidarity, LC/G.2294(SES.31/3), Santiago, Chile.

Fay, Marianne and Mary Morrison (2005): Infrastructure in Latin America and the Caribbean: Recent Developments and Key Challenges, Washington, D.C., World Bank.

Filc, Gabriel and Carlos Scartascini (2006): Budgetary institutions, in Eduardo Lora (ed.), The State of State Reform in Latin America, Washington, D.C., Inter-American Development Bank.

Gavin, Michael and Roberto Perotti (1997): Fiscal policy in Latin America, NBER Macroeconomics Annual 1997, No. 12, Cambridge, Massachusetts, MIT Press.

Gill, Indermit, Truman Packard and Juan Yermo (2005): Keeping the Promise of Social Security in Latin America, Washington, D.C., World Bank.

Gupta, Sanjeev and Marijn Verhoeven (2001): The efficiency of government expenditure: experiences from Africa, Journal of Policy Modeling, vol. 23, Amsterdam, Elsevier.

Hammouya, Messaoud (1999): Statistics on Public Sector Employment, Methodology, Structure and Trends, Geneva, International Labour Office.

Herrera, Santiago and Gaobo Pang (2005): Efficiency of Public Spending in Developing Countries: An Efficiency Frontier Approach, World Bank Policy Research Working Paper, No. 3645, Washington, D.C., World Bank.

IDB (Inter-American Development Bank) (2005): The Politics of Policies, Washington, D.C.

33 The results for Colombia, however, should be interpreted with caution for a number of reasons (see main text for further discussion). 
(2006): Living With Debt: How to Limit the Risks of Sovereign Debt, Washington, D.C.

IMF (International Monetary Fund) (2003): World Economic Outlook: Public Debt in Emerging Markets, Washington, D.C., September.

(2005): Public Investment and Fiscal Policy. Lessons from the Pilot Country Studies, Washington, D.C. Available in http://www.imf.org.

(2006a): Public-Private Partnerships, Government Guarantees, and Fiscal Risk, Washington, D.C.

(2006b): Regional Economic Outlook: Western Hemisphere, Washington, D.C., November.

(2007): Promoting Fiscal Discipline, Occasional Paper, Washington, D.C., Fiscal Affairs Department, forthcoming.

Kaminsky, Graciela L., Carmen Reinhart and Carlos Végh (2004): When it Rains, it Pours: Procyclical Capital Flows and Macroeconomic Policies, NBER Working Paper, No. 10780, Cambridge, Massachusetts, National Bureau of Economic Research.

Kaufmann, Daniel, Aart Kraay and Massimo Mastruzzi (2006): Governance Matters V: Governance Indicators for 1996-2005, Washington, D.C., World Bank.

Lindert, Kathy, Emmanuel Skoufias and Joseph Shapiro (2006): Redistributing Income to the Poor and the Rich: Public Transfers in Latin America and the Caribbean, Washington, D.C., World Bank.

Lopez-Claros, Augusto, Michael E. Porter and others (2006): The Global Competitiveness Report 2006-2007: Creating an Improved Business Environment, Geneva, World Economic Forum.

Mullis, I.V.S., M.O. Martin and others (2004a): TIMSS 2003 International Mathematics Report, Chestnut Hill, TIMSS \&
PIRLS International Study Center, Lynch School of Education, Boston College.

(2004b): TIMSS 2003 International Science Report, Chestnut Hill, TIMSS \& PIRLS International Study Center, Lynch School of Education, Boston College.

OECD (Organisation for Economic Co-operation and Development) (2001): Highlights of Public Sector Pay and Employment Trends, Paris. (2004): Learning for Tomorrow's World: First Results from PISA 2003, Paris.

Roldos, Jorge (2006): Pension Reform and Macroeconomic Stability, unpublished.

Sahay, Ratna and Rishi Goyal (2006): Volatility and Growth in Latin America: An Episodic Approach, IMF Working Paper, No. 06/287, Washington, D.C., International Monetary Fund.

Singh, Anoop and Martin Cerisola (2006): Sustaining Latin America's Resurgence: Some Historical Perspectives, IMF Working Paper, No. 06/252, Washington, D.C., International Monetary Fund.

Schiavo-Campo, Salvatore, Giulio de Tommaso and Amitabha Mukherjee (1997): An International Statistical Survey of Government Employment and Wages, Policy Research Working Paper, No. 1806, Washington, D.C., World Bank.

Stein, Ernesto, Ernesto Talvi and Alejandro Grisanti (1998): Institutional Arrangements and Fiscal Performance: The Latin American Experience, IADB Working Paper, No. 367, Washington, D.C., Inter-American Development Bank.

Talvi, Ernesto and Carlos Végh (2005): Tax base variability and procyclical fiscal policy, Journal of Development Economics, vol. 78, Amsterdam, Elsevier, October. 